\title{
Society For Pediatric Research MEMBERSHIP LIST 1973-1974 Active
}

Charles Abildgaard, M.D. Department of Pediatrics University of California, Davis Davis, Ca. 95616

Thomas Aceto, M.D. Buffalo Children's Hospital 219 Bryant Street Buffalo, N.Y. 14222

Peter A. J. Adam, M.D. Cleveland Metropolitan General Hospital 3395 Scranton Road

Cleveland, Ohio 44109

William H. Adler, M.D.

U.S. Army Research Institute of Infectious Diseases

Pathology Division

Ft. Detrick

Frederick, Md. 21701

E. Russell Alexander, M.D. Department of Preventive Medicine University of Washington School of Medicine Seattle, Washington 98105

Charles A. Alford, Jr., M.D. Department of Pediatrics University of Alabama Medical Center 1919 Seventh Avenue, South Birmingham, Alabama 35233

Chester A. Alper, M.D. Children's Hospital Medical Center 300 Longwood Ave.

Boston, Massachusetts 02115

Joel J. Alpert, M.D. Children's Hospital Medical Center Harvard Medical School 300 Longwood Ave. Boston, Massachusetts 02115

William A. Altemeier, III, M.D. Department of Pediatrics Metropolitan Nashville General Hospital 72 Hermitage Avenue Nashville, Tenn. 37210

Arthur J. Ammann, M.D. Department of Pediatrics University of California Medical Center San Francisco, California 94122

Bascom Anthony, M.D. Department of Pediatrics Harbor General Hospital 1000 W. Carson Street Torrance, California 90509
Victor H. Auerbach, M.D. St. Christopher's Hospital for Children 2600 N. Lawrence St. Philadelphia, Pennsylvania 19133

Gordon B. Avery, M.D., Ph.D. Department of Pediatrics George Washington University Children's Hospital of the D.C. 2125 13th Street N.W. Washington, D.C. 20009

Robert L. Baehner, M.D. Department of Pediatrics Indiana University School of Medicine Indianapolis, Indiana 46202

Lester Baker, M.D. Children's Hospital of Philadelphia 1740 Bainbridge Street Philadelphia, Pennsylvania 19139

Frederick C. Battaglia, M.D. University of Colorado Medical Center 4200 East Ninth Avenue Denver, Colorado 80220

Joseph V. Baublis, M.D. Dept. Pediatrics \& Communicable Diseases University of Michigan Medical Center Ann Arbor, Michigan 48104

Richard E. Behrman, M.D.

Department of Pediatrics College of Physicians \& Surgeons of Columbia University New York, N.Y. 10032

Jennifer Bell, M.D. Department of Pediatrics College of Physicians \& Surgeons of Columbia University 630 W. 168th St. New York, N.Y. 10032

Joseph A. Bellanti, M.D. Department of Pediatrics Georgetown University Medical Center German Building 3800 Reservoir Road N.W. Washington, D.C. 20007

Mark Belsey, M.D.

Human Reproduction Unit World Health Organization 1211 Geneva 27

Switzerland

Herschel P. Bentley, Jr., M.D. 3920 Airport Boulevard Mobile, Alabama 36608
Abraham B. Bergman, M.D.

Children's Orthopedic Hospital and Medical Center

Seattle, Washington 98105

Julian L. Berman, M.D.

Genetics Section

Cook County Children's Hospital

700 South Wood Street

Chicago, Illinois 60612

Merton R. Bernfield, M.D. Department of Pediatrics Stanford University Medical Center Stanford, California 94305

Edward B. Blau, M.D. Children's Hospital of Pittsburgh 125 DeSoto Street Pittsburgh, Pennsylvania 15213

Arthur David Bloom, M.D. Department of Human Genetics University of Michigan Medical School Ann Arbor, Michigan 48104

Gerald Bloom, M.D. Department of Pediatrics University of Florida College of Medicine Gainesville, Florida 32601

Hans Henning Bode, M.D. Children's Service Massachusetts General Hospital Boston, Massachusetts 02114

John P. Boineau, M.D. Duke University Medical Center Durham, North Carolina 27706

Luis Borella, M.D.

St. Jude Children's Research Hospital 332 N. Lauderdale P.O. Box 318 Memphis, Tennessee 38101

June P. Brady, M.D. Department of Pediatrics Children's Hospital, Room 211 3700 California Street San Francisco, California 94119

JoAnne Brasel, M.D.

Department of Pediatrics

The New York Hospital-Cornell

Medical Center

525 East 68th Street New York, N.Y. 10021 
David M. Brown, M.D.

Department of Pediatrics

1460 Mayo

University of Minnesota

Minneapolis, Minnesota 55455

Phillip A. Brunell, M.D.

Department of Pediatrics

New York University School of Medicine

550 First Avenue

New York, N.Y. 10016

George T. Bryan, M.D.

Department of Pediatrics

University of Texas Medical Branch

Galveston, Texas 77550

Rebecca Buckley, M.D.

Department of Pediatrics

Duke University Medical Centex

Durham, North Carolina 27706

Francis C. Cadigan, Jr., M.D.

Director of Medical Research

U.S. Army Med. R. \& D. Command

Washington, D.C. 20314

Luis Canales, M.D.

Pediatric Service

Brooke General Hospital

Fort Sam Houston, Texas 78234

Ramon V. Canent, Jr., M.D.

Division of Pediatric Cardiology

Department of Pediatrics

Duke University Medical Center

Durham, North Carolina 27706

Howard M. Cann, M.D.

Department of Pediatrics

Stanford University School of Medicine 300 Pasteur Drive

Palo Alto, California 94305

David H. Carver, M.D.

Johns Hopkins Hospital

601 N. Broadway

Baltimore, Maryland 21205

George E. Cassady, II, M.D.

Director of Perinatal Medicine

University of Alabama Medical Center

Birmingham, Alabama 35200

Salvador Castells, M.D.

Department of Pediatrics

State University of New York

450 Clarkson Avenue

Brooklyn, N.Y. 11203

Evan Charney, M.D.

Department of Pediatrics

260 Crittenden Boulevard

Rochester, New York 14620
H. Peter Chase, M.D.

Department of Pediatrics

University of Colorado Medical Center

4200 East Ninth Avenue

Denver, Colorado 80200

Victor Chernick, M.D.

Department of Pediatrics

University of Manitoba

Winnipeg, Manitoba, Canada

James D. Cherry, M.D.

Cardinal Glennon Memorial Hospital

1465 South Grand Boulevard

St. Louis, Missouri 63104

Robert O. Christiansen, M.D.

Department of Pediatrics

Stanford Medical Center

Stanford, California 94305

Wallace A. Clyde, Jr., M.D.

Department of Pediatrics

School of Medicine

University of North Carolina

Chapel Hill, North Carolina 27514

Maimon M. Cohen, Ph. D.

Children's Hospital

Division of Human Genetics

219 Bryant Street

Buffalo, New York 14222

Michael Cohen, M.D.

Department of Pediatrics

Mon tefiore Hospital and Medical Center

111 East 210th Street

Bronx, New York 10467

Sanford Cohen, M.D.

Department of Pharmacology

New York University School of Medicine

550 First Avenue

New York, N.Y. 10016

Platon J. Collipp, M.D.

Meadowbrook Hospital

East Meadow, New York 11554

Robert Collu, M.D.

L'Hôpital Sain te Justine

3175 Chemin Ste. Catherine

Montreal 250, Quebec, Canada

Harvey R. Colten, M.D.

Children's Hospital Medical Center

300 Longwood Avenue

Boston, Mass 02115

Louis Z. Cooper, M.D.

New York University Medical Center

550 First Avenue

New York, N.Y. 10016
Max D. Cooper, M.D.

Department of Pediatrics

University of Alabama, Birmingham

Birmingham, Alabama 35223

James J. Corrigan, Jr., M.D.

Department of Pediatrics

University of Arizona College of Medicine

Tucson, Arizona 85721

Jean A. Cortner, M.D.

Department of Pediatrics

School of Medicine

State University of New York at Buffalo

219 Bryant Street

Buffalo, N.Y. 14222

Marilyn L. Cowger, M.D.

Department of Chemistry

State University of New York

Albany, New York 12203

Henry G. Cramblett, M.D.

The Children's Hospital

17th Street at Livingston Park

Columbus, Ohio 43205

Gerd J. A. Cropp, M.D., Ph.D.

Department of Pediatrics

University of Colorado Medical Center

4200 East Ninth Avenue

Denver, Colorado 80220

William J. Daily, M.D.

Good Samaritan Hospital

1033 East McDowell Road

Phoenix, Arizona 85006

Adnan S. Dajani, M.D.

Department of Pediatrics

University of Minnesota Medical School

Minneapolis, Minnesota 55455

Louis Dallaire, M.D.

L'Hôpital Sainte-Justine

3175 Chemin Ste. Catherine

Montreal 250, Quebec, Canada

Peter R. Dallman, M.D.

Department of Pediatrics

University of California

San Francisco Medical Center

San Francisco, California 94122

Ronald Davidson, M.D.

Division of Human Genetics

Department of Pediatrics

Children's Hospital

219 Bryant Street

Buffalo, New York 14222 


\section{SPR Active}

Starkey D. Davis, M.D.

Department of Pediatrics

University of Washington School of Medicine

Seattle, Washington 98105

Robert W. Day, M.D.

Department of Preventive Medicine

University of Washington School of Medicine

Seattle, Washington 98105

Maria Delivoria-Papadopoulos, M.D.

Graduate Department of Physiology

University of Pennsylvania

School of Medicine

Philadelphia, Pennsylvania 19104

Ralph B. Dell, M.D.

Department of Pediatrics

Columbia-Presbyterian Medical Center

630 West 168th Street

New York, N.Y. 10032

Hugh C. Dillon, M.D.

Department of Pediatrics

University of Alabama

Birmingham, Alabama 35233

Philip R. Dodge, M.D.

Department of Pediatrics

Washington University School of Medicine

St. Louis, Missouri 63110

Warren F. Dodge, M.D.

Department of Pediatrics

University of Texas Medical Center

Galveston, Texas 77551

Carl Doershuk, M.D.

Babies and Children's Hospital Case Western Reserve University

School of Medicine

Cleveland, Ohio 44106

S. Evans Downing, M.D.

Yale University School of Medicine

Pathology Department

310 Cedar Street

New Haven, Connecticut 06510

Robert H. Drachman, M.D.

Department of Pediatrics-CMSC 1101

The Johns Hopkins Hospital

601 North Broadway

Baltimore, Maryland 21205

Allan L. Drash, M.D.

Children's Hospital of Pittsburgh

125 DeSoto Street

Pittsburgh, Pennsylvania 15213
Keith N. Drummond, M.D.

The Mon treal Children's Hospital

2300 Tupper Street

Montreal 25, Quebec

Canada

Reuben S. Dubois, M.D.

Department of Pediatrics

University of Colorado Medical Center

4200 East Ninth Avenue

Denver, Colorado 80220

Claire Hammel DuPont, M.D.

1 Haverstock Road

Hampstead, Montreal

P.Q., Canada

Chester M. Edelmann, Jr., M.D.

Department of Pediatrics

Albert Einstein College of Medicine

Eastchester Road and Morris Park Avenue

Bronx, N.Y. 10461

M. Joycelyn Elders, M.D.

Department of Pediatrics

University of Arkansas Medical Center

Little Rock, Arkansas 72201

Elliot F. Ellis, M.D.

National Jewish Hospital Research Center 3800 East Colfax Avenue

Denver, Colorado 80206

Charles J. Epstein, M.D.

Department of Pediatrics

University of California

San Francisco Medical Center

San Francisco, California 94122

John R. Esterly, M.D

Chicago Lying-In Hospital

University of Chicago

Chicago, Illinois 60637

Nancy B. Esterly, M.D.

Department of Dermatology

Abraham Lincoln School of the

College of Medicine

University of Illinois

Chicago, Illinois 60612

Hugh E. Evans, M.D.

Department of Pediatrics

Harlem Hospital Center

135th Street and Lenox Avenue

New York, N.Y. 10037

Ralph Feigin, M.D.

Department of Pediatrics

St. Louis Children's Hospital

500 South Kingshighway

St. Louis, Missouri 63110
Gerald Wallace Fernald, M.D.

Department of Pediatrics

University of North Carolina

School of Medicine

Chapel Hill, North Carolina 27514

Richard N. Fine, M.D.

Children's Hospital of Los Angeles

4650 Sunset Blvd.

Los Angeles, California 90027

Chester W. Fink, M.D.

Department of Pediatrics

The University of Texas

Southwestern Medical School

5323 Harry Hines Blvd.

Dallas, Texas 75235

Jordan W. Finkelstein, M.D. Department of Pediatrics Montefiore Hospital and Medical Center 111 East 210th Street Bronx, New York 10467

Jerry Z. Finklestein, M.D. Department of Pediatrics Harbor General Hospital 1000 W. Carson Street

Torrance, California 90509

Philip Fireman, M.D.

University of Pittsburgh

Department of Pediatrics

Children's Hospital of Pittsburgh

Pittsburgh, Pennsylvania 15213

Alfred J. Fish, M.D.

Department of Pediatrics Box 441

University of Minnesota Hospitals

University of Minnesota

Minneapolis, Minnesota 55455

Delbert A. Fisher, M.D.

Department of Pediatrics

UCLA School of Medicine

Harbor General Hospital

1000 West Carson Street

Torrance, California 90509

Michael M. Frank, M.D.

Clinical Immunology Section

Laboratory of Clinical Investigation

NIAID, Building 10, Room 11N-104

National Institutes of Health

Bethesda, Maryland 20014

William K. Frankenburg, M.D.

Department of Pediatrics

University of Colorado Medical Center

4200 East Ninth Avenue

Denver, Colorado 80220 


\section{SPR Active}

S. Douglas Frasier, M.D.

Children's Division

Los Angeles County General Hospital

1200 North State Street

Los Angeles, California 90033

John M. Freeman, M.D.

The Johns Hopkins Hospital

601 North Broadway

Baltimore, Maryland 21205

Frank S. French, M.D.

Department of Pediatrics

The University of North Carolina

School of Medicine

Chapel Hill, North Carolina 27514

Joseph H. French, M.D.

Montefiore Hospital and Medical Center

111 East 210th Street

Bronx, New York 10467

Stanford B. Friedman, M.D.

Department of Pediatrics

University of Rochester

School of Medicine

Rochester, New York 14620

William F. Friedman, M.D.

Cardiovascular Division

University of California, San Diego

School of Medicine

La Jolla, California 92155

Theodore Friedmann, M.D.

Department of Pediatrics

University of California, San Diego

School of Medicine, P.O. Box 109

La Jolla, California 92037

Vincent A. Fulginiti, M.D.

Department of Pediatrics

University of Arizona School of Medicine

Tucson, Arizona 85724

Lawrence M. Gartner, M.D.

Department of Pediatrics

Albert Einstein College of Medicine New York, N.Y. 10461

Richard A. Gatti, M.D.

University of Minnesota Hospitals

Mayo Box 494

Minneapolis, Minnesota 55455

Gerald E. Gaull, M.D.

Department of Pediatric Research

New York State Institute for Basic

Research in Mental Retardation

1050 Forest Hill Road

Staten Island, N.Y. 10314
Welton M. Gersony, M.D.

Department of Pediatrics

College of Physicians \& Surgeons

630 W. 168th Street

New York, N.Y. 10032

Ira H. Gessner, M.D.

Department of Pediatrics

University of Florida College of Medicine

Gainesville, Florida 32603

Henry Gewurz, M.D.

Department of Immunology

Rush-Presby terian-St. Luke's Medical Center

1753 West Congress Parkway

Chicago, Illinois 60612

Samuel T. Giammona, M.D.

Department of Pediatrics

Children's Hospital of San Francisco

3700 California Street

San Francisco, California 94119

Gerald S. Gilchrist, M.D.

Mayo Clinic

Rochester, Minnesota 55901

Philip R. Glade, M.D.

Mount Sinai School of Medicine

Department of Pediatrics

New York, N.Y. 10029

Lowell A. Glasgow, M.D.

Department of Microbiology

University of Utah Medical Center

Salt Lake City, Utah 84112

Leonard Glass, M.D.

Department of Pediatrics

Harlem Hospital Center

New York, New York 10037

William Paul Glezen, M.D.

Department of Pediatrics

University of North Carolina

School of Medicine

Chapel Hill, North Carolina 27514

Ronald Gold, M.D.

Department of Pediatrics

University of Connecticut Health Center

McCook Hospital

2 Holcomb Street

Hartford, Connecticut 06112

Stanley J. Goldberg, M.D.

Department of Pediatrics

University of Arizona Medical Center

Tucson, Arizona 85724
Allen S. Goldman, M.D.

The Children's Hospital of Philadelphia

1740 Bainbridge Street

Philadelphia, Pennsylvania 19139

Armond S. Goldman, M.D.

Department of Pediatrics

University of Texas Medical Branch

Galveston, Texas 77550

Leon Gordis, M.D.

Department of Epidemiology

Johns Hopkins School of Hygiene

and Public Health

615 North Wolfe Street

Baltimore, Maryland 21205

Samuel P. Gotoff, M.D.

Department of Pediatrics

University of Illinois College of Medicine 840 South Wood Street

Chicago, Illinois 60612

Thomas P. Graham, Jr., M.D.

6511 Brownlee Drive

Nashville, Tennessee 37205

Richard J. Grand, M.D.

Children's Hospital Medical Center

300 Longwood Avenue

Boston, Mass. 02115

Stanley N. Graven, M.D.

Hartford Neonatal Research Laboratories

St. Mary's Hospital

720 South Brooks Street

Madison, Wisconsin 53715

Leonard J. Graziani, M.D.

Departments of Pediatrics and Neurology

Jefferson Medical College

1025 Walnut Street

Philadelphia, Pennsylvania 19107

Robert E. Greenberg, M.D.

Department of Pediatrics

Charles R. Drew Postgraduate Medical School

1620 E. 119th Street

Los Angeles, California 90059

George A. Gregory, M.D.

Departments of Pediatrics and Anesthesia University of California, San Francisco

San Francisco, California 94122

John F. Griffith, M.D.

Department of Pediatrics

P.O. Box 2975

Duke University Medical Center

Durham, North Carolina 27706 


\section{SPR Active}

Warren E. Grupe, M.D.

Babies and Childrens Hospital

2103 Adelbert Road

Cleveland, Ohio 44106

Joyce D. Gryboski, M.D.

Department of Pediatrics

Yale University School of Medicine

New Haven, Connecticut 06510

Harvey J. Guyda, M.D.

Montreal Children's Hospital

2300 Tupper Street

Montreal 108, Quebec, Canada

Kenneth C. Haltalin, M.D.

Department of Pediatrics

The University of Texas (Southwestern)

Medical School at Dallas

5323 Harry Hines Blvd.

Dallas, Texas 75235

John L. Hamerton, M.D.

The Department of Genetics

Children's Hospital of Winnipeg

685 Bannatyne Avenue

Winnipeg 3, Manitoba, Canada

J. Richard Hamilton, M.D.

The Hospital for Sick Children

555 University Avenue

Toronto 2, Ontario, Canada

James B. Hanshaw, M.D.

Department of Pediatrics

The Genessee Hospital

224 Alexander Street

Rochester, New York 14620

William E. Hathaway, M.D.

2090 Ash

Denver, Colorado 80207

Frederick Hecht, M.D.

Crippled Children's Division

Department of Pediatrics

University of Oregon Medical School

3181 S.W. Sam Jackson Park Rd.

Portland, Oregon 97201

Michael A. Heymann, M.D.

Department of Pediatrics

University of California Medical Center

San Francisco, California 94122

L. Leighton Hill, M.D.

Department of Pediatrics

Baylor University College of Medicine

1200 Moursund Avenue

Houston, Texas 77025
William Alan Hodson, M.D.

Department of Pediatrics

University of Washington School of Medicine

Seattle, Washington 98105

Philip Holland, M.D.

Department of Pediatrics

University of Kentucky Medical Center

Lexington, Kentucky 40506

Lewis B. Holmes, M.D.

Genetics Unit

Massachusetts General Hospital

Boston, Massachusetts 02114

Philip G. Holtzapple, M.D.

The Children's Hospital of Philadelphia

1740 Bainbridge Street

Philadelphia, Pennsylvania 19146

Neil A. Holtzman, M.D.

Department of Pediatrics

The Johns Hopkins Hospital

Baltimore, Maryland 21205

Richard Hong, M.D.

Professor of Pediatrics

University of Wisconsin

Madison, Wisconsin 53706

George R. Honig, M.D.

Department of Pediatrics

University of Illinois

840 South Wood Street

Chicago, Illinois 60612

Ernest B. Hook, M.D.

Laboratory of Human Biology

Birth Defects Institute

Department of Pediatrics

Albany Medical College

Albany, New York 12208

John C. Houck, M.D.

Research Foundation of Children's Hospital

2125 Thirteenth Street N.W.

Washington, D.C. 20009

William F. Howatt, M.D.

Department of Pediatrics and Communicable Diseases

University of Michigan Medical Center Ann Arbor, Michigan 48104

R. Rodney Howell, M.D.

Department of Pediatrics

Johns Hopkins Hospital

Baltimore, Maryland 21205

Yujen E. Hsia, M.D.

Yale University School of Medicine

333 Cedar Street

New Haven, Connecticut 06510
Lillian Yu-Feng Hsu, M.D.

Department of Pediatrics

The Mount Sinai Hospital

Fifth Avenue and One Hundredth Street

New York, N.Y. 10029

George Hug, M.D.

The Children's Hospital Research

Foundation

Elland Avenue and Bethesda

Cincinnati, Ohio 45229

Edwin R. Hughes, M.D.

Department of Pediatrics

University of West Virginia Medical Center

Morgantown, West Virginia 26505

Wellington Hung, M.D.

Children's Hospital of D.C.

2125 13th Street N.W.

Washington, D.C. 20009

Peter R. Huttenlocher, M.D

Yale University School of Medicine

333 Cedar Street

New Haven, Connecticut 06510

Robert P. Igo, M.D.

Department of Pediatrics

University of Washington

School of Medicine

Seattle, Washington 98105

M. M. Jarmakani, M.D.

Department of Pediatrics

Box 3068

Duke University School of Medicine

Durham, North Carolina 27706

Richard B. Johnston, Jr., M.D.

Departments of Pediatrics and Microbiology

University of Alabama Medical Center

Birmingham, Alabama 35294

Richard C. Juberg, M.D., Ph.D.

L.S.U. School of Medicine in Shreveport

P.O. Box 3932

Shreveport, Louisiana 71130

Michael M. Kaback, M.D.

Department of Pediatrics

Harbor General Hospital

1000 West Carson Street

Torrance, California 90509

Myron Karon, M.D.

Children's Hospital

P.O. Box 54700, Terminal Annex

Los Angeles, California 90054 


\section{SPR Active}

Margaret H. Karpatkin, M.D. Department of Pediatrics New York University Medical School 550 First Avenue New York, New York 10016

Emanuel Kauder, M.D. Barney Children's Medical Center 1735 Chapel Street

Dayton, Ohio 45405

Haig H. Kazazian, Jr., M.D. Department of Pediatrics Johns Hopkins University School of Medicine Baltimore, Maryland 21205

Robert C. Kelsch, M.D. Department of Pediatrics and Communicable Diseases

R 6028 Kresge II

University of Michigan Medical Center Ann Arbor, Michigan 48104

Frederic M. Kenny, M.D. Children's Hospital of Pittsburgh 125 DeSoto Street Pittsburgh, Pennsylvania 15213

Jean Bryce Felty Kenny, M.D. Children's Hospital of Pittsburgh 125 Desota Street Pittsburgh, Pennsylvania 15213

\section{George R. Kerr, M.D.}

Department of Pediatrics University of Wisconsin Medical Center 1300 University Avenue Madison, Wisconsin 53706

B. S. Langford Kidd, M.D. Department of Cardiology Hospital for Sick Children 555 University Avenue Toronto, Ontario, Canada

Marcel Kinsbourne, M.D., Ph.D. Department of Pediatrics Duke University School of Medicine Durham, North Carolina 27706

C. Thomas Kisker, M.D. Children's Hospital Research Foundation Elland \& Bethesda Avenues Cincinnati, Ohio 45229

Jerome O. Klein, M.D. Department of Pediatrics Boston City Hospital 818 Harrison Avenue Boston, Massachusetts 02118

Martin Klemperer, M.D. 300 Longwood Avenue Boston, Massachusetts 02115
William T. Kniker, M.D.

Department of Pediatrics

University of Texas Medical School at San Antonio

7703 Floyd Curl Drive

San Antonio, Texas 78229

J. L. Knittle, M.D.

Department of Pediatrics

The Mt. Sinai School of Medicine

100th Street and Fifth Avenue

New York, New York 10029

Maurice D. Kogut, M.D.

Children's Hospital of Los Angeles

4614 Sunset Blvd.

Los Angeles, California 90027

Gertrude Kohn, M.D.

Children's Hospital of Philadelphia

1740 Bainbridge Street

Philadelphia, Pennsylvania 19146

Diane M. Komp, M.D.

Department of Pediatrics

University of Virginia School of Medicine

Charlottesville, Virginia 22901

Stella B. Kontras, M.D.

Department of Pediatrics

Ohio State University College of Medicine

Children's Hospital

Columbus, Ohio 43205

Sang Whay Kooh, M.D.

Research Institute

The Hospital for Sick Children

555 University Avenue

Toronto 2, Ontario, Canada

L. Jerome Krovetz, M.D.

Department of Pediatrics

Johns Hopkins Hospital

Baltimore, Maryland 21205

Howard E. Kulin, M.D.

Department of Pediatrics

M.S. Hershey Medical Center

Hershey, Pennsylvania 17033

Beatrice Lampkin, M.D.

Children's Hospital Research Foundation

Elland Avenue and Bethesda

Cincinnati, Ohio 45229

David J. Lang, M.D.

Children's Medical Service

Massachusetts General Hospital

Boston, Massachusetts 02114

Philip Lanzkowsky, M.D.

Department of Pediatrics

Long Island Jewish Medical Center

New Hyde Park, N.Y. 11040
R. P. Bryce Larke, M.D.

Department of Pediatrics

McMaster University

Hamilton, Ontario, Canada

Ronald M. Lauer, M.D.

Department of Pediatrics

Pediatric Cardiology Section

University of Iowa Hospital

Iowa City, Iowa 52240

Gilles Leboeuf, M.D.

L'Hôpital Sainte-Justine

3175 Chemin Sainte-Catherine

Montreal 26, Quebec, Canada

Martin H. Lees, M.D.

Department of Pediatrics

University of Oregon Medical School

3181 S.W. Sam Jackson Blvd.

Portland, Oregon 97201

Ronald J. Lemire, M.D.

Department of Pediatrics

University of Washington

Seattle, Washington 98105

Jacques Letarte, M.D.

Section of Endocrinology \& Metabolism L'Hôpital Sainte Justine 3175 Cote Sainte-Catherine Road Montreal 250, Quebec, Canada

Brigid G. Leventhal, M.D.

Leukemia Service

National Cancer Institute

National Institutes of Health

Bethesda, Maryland 20014

Aaron Levin, M.D.

The New York Hospital

Cornell University Medical Center

525 East 68th Street

New York, N.Y. 10021

Ephraim Y. Levin, M.D.

Department of Pediatrics

The Johns Hopkins University

School of Medicine

Baltimore, Maryland 21205

Henry Levison, M.D.

The Hospital for Sick Children

555 University Avenue

Toronto 2, Canada

Harvey Levy, M.D.

Neurology Research

Massachusetts General Hospital

Boston, Massachusetts 02114 
John E. Lewy, M.D.

Department of Pediatrics

Cornell University Medical College

1300 York Avenue

New York, N.Y. 10021

Ellin Lieberman, M.D.

Children's Hospital of Los Angeles

4650 Sunset Blvd.

Los Angeles, California 90054

Paul S. Lietman, M.D.

Department of Pediatrics

Johns Hopkins Hospital

Baltimore, Maryland 21205

Fima Lifshitz, M.D.

Chief, Pediatric Research

North Shore Hospital and

Cornell University Medical College

300 Community Drive

Manhasset, New York 11030

Irwin J. Light, M.D.

Department of Pediatrics

Children's Hospital Research Foundation

Elland Avenue and Bethesda

Cincinnati, Ohio 45229

Leonard M. Linde, M.D.

10921 Wilshire Boulevard

Suite 606

Los Angeles, California 90024

Philip J. Lipsitz, M.D.

Department of Pediatrics

Beth Israel Medical Center

10 Nathan Perlman Place

New York, N.Y. 10003

J. Alexander Lowden, M.D.

The Research Institute

The Hospital for Sick Children

555 University Avenue

Toronto 101, Ontario, Canada

James T. Lowman, M.D.

Department of Pediatrics

University of Kansas Medical Center

Rainbow Blvd. and 39th Street

Kansas City, Kansas 66103

Russell V. Lucas, Jr., M.D.

University of Minnesota Medical School

Minneapolis, Minnesota 55455

John N. Lukens, M.D.

Department of Pediatrics

Charles R. Drew Postgraduate

Medical School

1620 East 119th Street

Los Angeles, California 90059
George M. Lyon, Jr., M.D.

Department of Pediatrics

Duke University Medical Center

Durham, North Carolina 27706

C. Charlton Mabry, M.D.

Department of Pediatrics

University of Kentucky Medical Center

Lexington, Kentucky 40506

Margaret MacGillivray, M.D.

Division of Human Genetics

Children's Hospital

86 Hodge Avenue

Buffalo, New York 14222

John A. Mangos, M.D.

Department of Pediatrics

University of Wisconsin Medical Center

1300 University Avenue

Madison, Wisconsin 53706

James F. Marks, M.D.

Department of Pediatrics

University of Texas Medical School

5323 Harry Hines Blvd.

Dallas, Texas 75235

Reuben Matalon, M.D.

Department of Pediatrics

The University of Chicago

5825 Maryland Avenue

Chicago, Illinois 60637

Allen W. Mathies, Jr., M.D.

LAC-USC Medical Center

Pediatric Pavilion

1200 North State Street

Los Angeles, California 90033

Alvin M. Mauer, M.D.

Department of Pediatrics

Medical College of Virginia

P.O. Box 121

Richmond, Virginia 23219

George H. McCracken, Jr., M.D.

Department of Pediatrics

The University of Texas

Southwestern Medical School at Dallas

5323 Harry Hines Blvd.

Dallas, Texas 75235

Rawle M. McIntosh, M.D.

Department of Pediatrics

College of Physicians \& Surgeons

630 W. 168th Street

New York, N.Y. 10032

Guy M. McKhann, M.D.

Department of Neurology

The Johns Hopkins University

School of Medicine

Baltimore, Mary land 21205
Donald N. Medearis, Jr., M.D.

Dean, School of Medicine

University of Pittsburgh

350 Terrace

Pittsburgh, Pennsylvania 15213

William J. Mellman, M.D.

Hospital of the University of Pennsylvania 3600 Spruce Street

Philadelphia, Pennsylvania 19146

Stanley A. Mendoza, M.D.

Department of Pediatrics

University of California, San Diego

La Jolla, California 92037

John H. Menkes, M.D.

Department of Pediatrics

UCLA School of Medicine

Los Angeles, California 90024

Harry M. Meyer, Jr., M.D.

Laboratory of Virology and Rickettsiology

Division of Biologics Standards

National Institutes of Health

Bethesda, Maryland 20014

Alfred F. Michael, M.D.

Department of Pediatrics

University of Minnesota Medical School

Minneapolis, Minnesota 55455

Barbara Rubin Migeon, M.D.

Department of Pediatrics

The Johns Hopkins Hospital

Baltimore, Maryland 21205

Denis R. Miller, M.D.

Department of Pediatrics

New York Hospital-Cornell Medical Center

525 E. 68th Street

New York, N.Y. 10021

John J. Miller, III, M.D.

Department of Pediatrics

Stanford University School of Medicine

Stanford, California 94305

Michael Miller, M.D.

Department of Pediatrics

Charles R. Drew Postgraduate Medical School 1620 East 119 th Street

Los Angeles, California 90059

Sanford Arthur Miller, M.D.

Department of Nutrition and Food Science

Massachusetts Institute of Technology

Cambridge, Massachusetts 02139

Charles E. Mize, M.D.

Department of Pediatrics

University of Texas Medical School at Dallas

5323 Harry Hines Blvd.

Dallas, Texas 75235 


\section{SPR Active}

James H. Moller, M.D.

Box 447

University of Minnesota Hospitals

Minneapolis, Minnesota 55455

John R. Montgomery, M.D.

Department of Pediatrics

Baylor College of Medicine

1200 Moursund Avenue

Houston, Texas 77025

Robert Y. Moore, M.D.

Section of Pediatric Neurology

Department of Pediatrics

University of Chicago School of Medicine

Chicago, Illinois 60637

Thomas J. Moore, M.D.

St. Luke's Hospital Center

Amsterdam Avenue at 114th Street

New York, N.Y. 10026

Akira Morishima, M.D.

Babies Hospital

622 West 168th Street

New York, N.Y. 10032

Grant Morrow, III, M.D.

Department of Pediatrics

University of Arizona

College of Medicine

Tucson, Arizona 85724

Etsuro Motoyama, M.D.

Department of Pediatrics

Yale University School of Medicine

333 Cedar Street

New Haven, Connecticut 06510

Ursula Müller-Eberhard, M.D.

Department of Biochemistry

Scripps Clinic \& Research Foundation

476 Prospect Street

La Jolla, California 92037

Henry L. Nadler, M.D.

Children's Memorial Hospital

2300 Children's Plaza

Chicago, Illinois 60614

Richard L. Naeye, M.D.

Department of Pathology

M.S. Hershey Medical Center

Hershey, Pennsylvania 17033

Andre J. Nahmias, M.D.

Department of Pediatrics

Emory University School of Medicine

69 Butler Street S.E.

Atlanta, Georgia 30303
J. Lawrence Naiman, M.D.

St. Christopher's Hospital for Children

2600 North Lawrence Street

Philadelphia, Pennsylvania 19133

David G. Nathan, M.D.

Department of Pediatrics

300 Longwood Avenue

Boston, Massachusetts 02115

Gerald Nathenson, M.D.

Department of Pediatrics

Montefiore Hospital and Medical Center

111 East 210th Street

Bronx, New York 10467

Robert C. Neerhout, M.D.

Department of Pediatrics

University of California

Center for the Health Sciences

10833 Le Conte Avenue

Los Angeles, California 90024

John M. Neff, M.D.

Department of Pediatrics

The Johns Hopkins Medical School

Baltimore, Maryland 21205

Allen H. Neims, M.D.

Department of Pediatrics

The Johns Hopkins University

School of Medicine

Baltimore, Maryland 21205

John Douglas Nelson, M.D.

Department of Pediatrics

The University of Texas

Southwestern Medical School

5323 Harry Hines Blvd.

Dallas, Texas 75235

Nicholas M. Nelson, M.D.

221 Longwood Avenue

Boston, Massachusetts 02115

Maria I. New, M.D.

Cornell University Medical College

1300 York Avenue

New York, N.Y. 10021

Buford L. Nichols, M.D.

Department of Pediatrics

Texas Medical Center

Houston, Texas 77025

Warren W. Nichols, M.D. Institute for Medical Research Sheridan \& Copewood Streets Camden, New Jersey 08104

John F. Nicholson, M.D. Department of Pediatrics College of Physicians \& Surgeons 630 W. 168th Street New York, N.Y. 10032
Jacqueline A. Noonan, M.D. Department of Pediatrics University of Kentucky Medical Center Lexington, Kentucky 40506

James J. Nora, M.D. Department of Pediatrics University of Colorado Medical Center 4200 East Ninth Avenue Denver, Colorado 80220

Milan Novak, CSc. Department of Pediatrics University of Miami School of Medicine P.O. Box 875

Miami, Florida 33152

William Odell, M.D. UCLA School of Medicine Harbor General Hospital 1000 West Carson Street Torrance, California 90509

Margaret E. O'Flynn, M.D. The Children's Memorial Hospital 2300 Children's Plaza Chicago, Illinois 60614

Pearay L. Ogra, M.D. Children's Hospital Virology Department 219 Bryant Street Buffalo, New York 14222

William Oh, M.D. Department of Pediatrics UCLA School of Medicine Division of Neonatology Harbor General Hospital 1000 West Carson Street Torrance, California 90509

John Marius Opitz, M.D. Departments of Pediatrics and Medical Genetics University of Wisconsin Medical Center 1300 University Avenue Madison, Wisconsin 53706

June E. Osborn, M.D. 495 Medical Sciences University of Wisconsin School of Medicine Madison, Wisconsin 53706

Frank A. Oski, M.D. Department of Pediatrics SUNY, Upstate Medical Center Syracuse, New York 13210

George M. Owen, M.D.

Room 311, Ross Hall Children's Hospital Columbus, Ohio 43205 
Lauren M. Pachman, M.D. Division of Immunology Children's Memorial Hospital 2300 Children's Plaza Chicago, Illinois 60614

Arthur R. Page, M.D. Department of Pediatrics University of Minnesota Minneapolis, Minnesota 55455

Lyman A. Page, M.D. North Street Kennebunkport, Maine 04046

Paul D. Parkman, M.D. 4101 Glenridge Street Kensington, Maryland 20795

John C. Partin, M.D. Children's Hospital Research Foundation Elland and Bethesda Avenues Cincinnati, Ohio 45229

David S. Pearlman, M.D. Department of Pediatrics National Jewish Hospital 3800 East Colfax Avenue Denver, Colorado 80206

Howard A. Pearson, M.D. Department of Pediatrics Yale University School of Medicine New Haven, Connecticut 06510

Raymond D.A. Peterson, M.D. 18656 Dixie Highway Homewood, Illinois 60430

Roderic H. Phibbs, M.D. Department of Pediatrics University of California San Francisco Medical Center San Francisco, California 94122

Michel Philippart, M.D. Division of Pediatric Neurology Department of Pediatrics University of California Los Angeles, California 90024

Rosita S. Pildes, M.D. Department of Pediatrics Cook County Children's Hospital 700 South Wood Street Chicago, Illinois 60612

Leonard Pinsky, M.D. Cell Genetics Laboratory

Lady Davis Ins ${ }^{\prime}$ " ute for Medical Research Jewish General Jspital 3755 Cote Saint Catherine Road Montreal 249, Quebec, Canada
Sergio Piomelli, M.D.

New York University Medical Center 550 First Avenue

New York, N.Y. 10016

Donald A. Pious, M.D.

Department of Pediatrics

University of Washington

School of Medicine

Seattle, Washington 98105

I. Barry Pless, M.D.

442 Rugby Avenue

Rochester, New York 14619

Stanley A. Plotkin, M.D.

University of Pennsylvania

The Wistar Institute

Philadelphia, Pennsylvania 19104

J. Rainer Poley, M.D.

Children's Memorial Hospital

University of Oklahoma Health Sciences Center

P.O. Box 26901

Oklahoma City, Oklahoma 73190

Ian H. Porter, M.D.

Department of Pediatrics

Albany Medical College

Albany, New York 12208

Bernard Portnoy, M.D.

Infectious Disease Laboratory

University of Southern California

1200 North State Street

Los Angeles, California 90033

Arthur L. Prensky, M.D.

Department of Pediatrics

Washington University School of Medicine 500 South Kingshighway

St. Louis, Missouri 63110

Qutub H. Qazi, M.D.

Department of Pediatrics

SUNY, Downstate Medical Center

450 Clarkson Avenue

Brooklyn, New York 11203

W. Joseph Rahill, M.D.

Children's Hospital

219 Bryant Street

Buffalo, New York 14222

Salvatore Raiti, M.D.

University of Maryland Hospital

National Pituitary Agency

Baltimore, Maryland 21201
C. George Ray, M.D.
Children's
Orthopedic Hospital
and Medical Center

4800 San Point Way N.E.

Seattle, Washington 98105

Ekkehard W. Reimond, M.D.

Department of Pediatrics

The University of Texas

Southwestern Medical School at Dallas

5323 Harry Hines Boulevard

Dallas, Texas 75235

Owen Rennert, M.D.

Departments of Pediatrics and Biochemistry

University of Florida College of Medicine

Gainesville, Florida 32601

John W. Reynolds, M.D.

Children's Hospital

311 Pleasant Avenue

St. Paul, Minnesota 55102

John Charles Ribble, M.D.

The New York Hospital

Cornell Medical Center

525 East 68th Street

New York, N.Y. 10021

David L. Rimoin, M.D., Ph.D.

Division of Medical Genetics

Harbor General Hospital

1000 West Carson Street

Torrance, California 90509

John B. Robbins, M.D.

NICHHD

National Institutes of Health

Bethesda, Maryland 20014

Alex F. Robertson, M.D.

Department of Pediatrics

Ohio State University

College of Medicine

Columbus, Ohio 43221

Alan M. Robson, M.D.

Department of Pediatrics

Washington University School of Medicine

500 Kingshighway

St. Louis, Missouri 63110

Allen W. Root, M.D.

Division of Pediatrics

Albert Einstein Medical Center

York and Tabor Roads

Philadelphia, Pennsylvania 19141

Fred S. Rosen, M.D.

300 Longwood Avenue

Boston, Massachusetts 02115 


\section{SPR Active}

Leon E. Rosenberg, M.D. Department of Pediatrics Yale University School of Medicine 333 Cedar Street New Haven, Connecticut 06510

Arlan L. Rosenbloom, M.D. Department of Pediatrics University of Florida College of Medicine Gainesville, Florida 32601

Robert L. Rosenfield, M.D. Department of Pediatrics University of Chicago 950 E. 59th Street Chicago, Illinois 60637

Glenn C. Rosenquist, M.D. Department of Pediatrics The Johns Hopkins Hospital Baltimore, Maryland 21205

Amnon Rosenthal, M.D. Department of Cardiology The Children's Hospital Medical Center 300 Longwood Avenue Boston, Massachusetts 02115

Richard Rothberg, M.D. University of Chicago 950 E. 59th Street Chicago, Illinois 60637

Claude C. Roy, M.D. 3175 Chemin Ste. Catherine Montreal 250, P.Q. Canada

Frederick J. Samaha, M.D. Department of Neurology Children's Hospital of Pittsburgh Pittsburgh, Pennsylvania 15213

Douglas Sanderg, M.D. Department of Pediatrics P.O. Box 875, Biscayne Annex University of Miami Miami, Florida 33152

Emile M. Scarpelli, M.D. Department of Pediatrics Albert Einstein College of Medicine New York, N.Y. 10461

Richard J. Schain, M.D. Department of Pediatrics UCLA School of Medicine Los Angeles, California 90024

Gerold L. Schiebler, M.D. Department of Pediatrics University of Florida College of Medicine Gainesville, Florida 32601
David Schiff, M.D., Ph.D. Department of Pediatrics Clinical Sciences Building University of Alberta Medical School Edmonton 7, Alberta, Canada

Jerry A. Schneider, M.D. Department of Pediatrics University of California at San Diego School of Medicine La Jolla, California 92037

Martin L. Schulkind, M.D. Department of Pediatrics University of Florida College of Medicine Gainesville, Florida 32601

Joseph D. Schulman, M.D. Departments of Pediatrics and Ob/Gyn New York Hospital-Cornell Medical Center 525 East 68th Street New York, N.Y. 10021

Elias Schwartz, M.D. Children's Hospital of Philadelphia 1740 Bainbridge Street Philadelphia, Pennsylvania 19146

Robert H. Schwartz, M.D. Department of Pediatrics University of Rochester School of Medicine and Dentistry 260 Crittenden Blvd. Rochester, N.Y. 14602

C. Ronald Scott, M.D. Department of Pediatrics University of Washington School of Medicine Seattle, Washington 98105

Charles R. Scriver, M.D.

Laboratory of Biochemical Genetics Montreal Children's Hospital 2300 Tupper Street Montreal 25, Quebec, Canada

Dexter S. Y. Seto, M.D.

Johns Hopkins University School of Medicine

Departments of Pediatrics and Microbiology

601 N. Broadway

Baltimore, Maryland 21205

John Sever, M.D.

11901 Ledgerock Court

Potomac, Maryland 20854

Douglas R. Shanklin, M.D. The Chicago Lying-In Hospital 5841 Maryland Avenue Chicago, Illinois 60637
Daniel C. Shannon, M.D. Children's Service Massachusetts General Hospital Boston, Massachusetts 02115

Harvey L. Sharp, M.D. Department of Pediatrics Box 279 Mayo Memorial University of Minnesota School of Medicine Minneapolis, Minnesota 55455

Vivian E-an Shih, M.D. Massachusetts General Hospital Boston, Massachusetts 02114

A. Majid Shojania, M.D. Department of Hematology St. Boniface General Hospital St. Boniface, Manitoba, Canada

David B. Shurtleff, M.D. Department of Pediatrics University of Washington School of Medicine 1959 Pacific Avenue N.E. Seattle, Washington 98105

Joseph V. Simone, M.D. St. Jude Children's Research Hospital P.O. Box 318

Memphis, Tennessee 38101

Artemis P. Simopoulos, M.D. Division of Medical Sciences National Research Council National Academy of Sciences 2101 Constitution Avenue, N.W. Washington, D.C. 20418

John C. Sinclair, M.D. Department of Pediatrics McMaster University Hamilton, Ontario, Canada

Lucius F. Sinks, M.D. Department of Pediatrics Roswell Park Memorial Institute 666 Elm Street Buffalo, N.Y. 14203

Howard R. Sloan, M.D., Ph.D. National Heart and Lung Institute Building 10, Room 7N 323 National Institutes of Health Bethesda, Maryland 20014

William S. Sly, M.D. Division of Medical Genetics Departments of Pediatrics and Medicine Washington University School of Medicine 4550 Scott Avenue St. Louis, Missouri 63110 


\section{SPR Active}

David H. Smith, M.D.

The Children's Hospital Medical Center 300 Longwood Avenue

Boston, Massachusetts 02115

Clive C. Solomons, M.D.

University of Colorado Medical Center

4200 East Ninth Avenue

Denver, Colorado 80220

Mary Ann South, M.D.

Department of Pediatrics

Baylor College of Medicine

Texas Medical Center

Houston, Texas 77025

Lester F. Soyka, M.D.

Department of Pharmacology

University of Illinois

901 S. Wolcott

Chicago, Illinois 60612

Roger E. Spitzer, M.D.

Children's Hospital Research Foundation

Elland and Bethesda Avenue

Cincinnati, Ohio 45229

Alexander Spock, M.D.

Department of Pediatrics

Box 3075

Duke University School of Medicine

Durham, North Carolina 27706

Barbara Starfield, M.D.

Department of Pediatrics

The Johns Hopkins Hospital

601 North Broadway

Baltimore, Maryland 21205

Mark W. Steele, M.D.

Children's Hospital of Pittsburgh

125 DeSoto Street

Pittsburgh, Pennsylvania 15213

Leo Stern, M.D.

The Montreal Children's Hospital

2300 Tupper Street

Montreal 25, Quebec, Canada

Joseph W. St. Geme, Jr., M.D. Department of Pediatrics UCLA Medical School 1000 W. Carson Street Torrance, California 90509

Richard E. Stiehm, M.D. Department of Pediatrics UCLA Center for the Health Sciences Los Angeles, California 90024
Jose Strauss, M.D. Department of Pediatrics

University of Miami

School of Medicine

P.O. Box 875, Biscayne Annex

Miami, Florida 33152

Robert L. Summitt, M.D.

848 Adams Avenue

Memphis, Tennesse 38103

Philip Sunshine, M.D.

Department of Pediatrics

Stanford Medical Center

300 Pasteur Drive

Palo Alto, California 94304

Kenneth F. Swaiman, M.D

University of Minnesota Medical School Minneapolis, Minnesota 55455

Richard C. Talamo, M.D.

Immunology Unit

Children's Service

Massachusetts General Hospital

Boston, Massachusetts 02114

James L. Talbert, M.D.

Department of Pediatrics

University of Florida

College of Medicine

Gainesville, Florida 32601

Thomas M. Teree, M.D.

1720 Parker Road

Elmira, N.Y. 14901

M. Michael Thaler, M.D.

Department of Pediatrics

694 Moffitt Hospital

University of California Medical Center

San Francisco, California 94122

Otto G. Thilenius, M.D.

Department of Pediatrics

University of Chicago

950 East 59th Street

Chicago, Illinois 60637

William G. Thurman, M.D.

Department of Pediatrics

University of Virginia

School of Medicine

Charlottesville, Virginia 22904

Franklin H. Top, Jr., M.D.

U.S. Army Medical Component, SEATO

APO San Francisco, California 96346
Ramon Torres-Pinedo, M.D.

Department of Physiology

University of Puerto Rico

San Juan, Puerto Rico

Luther B. Travis, M.D

Division of Pediatric Nephrology

Department of Pediatrics

University of Texas Medical Branch

Galveston, Texas 77550

Virginia L. Tucker, M.D.

Department of Pediatrics

University of Kansas Medical Center

Kansas City, Kansas 66103

Robert H. Usher, M.D.

Neonatal Unit

Royal Victoria Hospital

Montreal 2, Canada

Richard Van Praagh, M.D.

Children's Hospital Medical Center

Cardiac Registry

300 Longwood Avenue

Boston, Massachusetts 02115

Joseph B. Warshaw, M.D.

Children's Service

Massachusetts General Hospital

Boston, Massachusetts 02114

Lester Weiss, M.D.

The Henry Ford Hospital

2799 West Grand Blvd.

Detroit, Michigan 48202

James G. White, M.D.

Department of Pediatrics

University of Minnesota Hospitals

Minneapolis, Minnesota 55455

John T. Wilson, M.D.

Department of Pediatrics

Vanderbilt University

School of Medicine

Nashville, Tennessee 37203

Myron Winick, M.D.

Institute of Human Nutrition

Columbia University

511 W. 166 th Street

New York, N.Y. 10032

J. S. D. Winter, M.D.

Children's Hospital of Winnipeg

685 Bannatyne Avenue

Winnipeg, Manitoba, Canada 
Paul Wong, M.D.

Department of Pediatrics

Mt. Sinai Hospital

California Avenue at 15th Street

Chicago, Illinois 60608

Harry T. Wright, Jr., M.D.

Division of Virology

Children's Hospital

P.O. Box 54700-Terminal Annex

Los Angeles, California 90054
M. Kabir Younoszai, M.D.

Department of Pediatrics

University Hospitals

Iowa City, lowa 52240

John B. Zabriskie, M.D.

The Rockefeller Institute New York, N.Y. 10021
Alvin Zipursky, M.D.

Department of Pediatrics

McMaster University

Hamilton, Ontario, Canada

Society For Pediatric Research

Membership Secretary

c/o Mrs. Franklin Matthies

Maplevale Drive

Woodbridge, Connecticut 06525 


\section{Society For Pediatric Research MEMBERSHIP LIST 1973-1974 \\ Emeritus}

Arthur F. Abt, M.D.

1101 St. Paul Street

Apt. 1605

Baltimore, Maryland 21202

Forrest Hood Adams, M.D. U.C.L.A. School of Medicine Los Angeles, California 90024

John Milton Adams, M.D. U.C.L.A. Medical Center Los Angeles, California 90024

Karlis Adamsons, M.D. Departments of Obstetrics and Gynecology

Mt. Sinai School of Medicine City University of New York 5 th Avenue \& 100 th Street New York, N.Y. 10029

Robert A. Aldrich, M.D. 500 Mohawk Drive, Apt. 307 Boulder, Colorado 80302

Fred H. Allen, Jr., M.D. Comm. Blood Council 310 E. 67th Street New York, N.Y. 10021

Richard J. Allen, M.D. Department of Pediatrics University Hospital Ann Arbor, Michigan 48104

Constantine S. Anast, M.D. Department of Pediatrics University of Missouri School of Medicine Columbia, Missouri 65201

Arthur F. Anderson, M.D. 69 Catalpa Road Wilton, Connecticut 06897

John A. Anderson, M.D.

Department of Pediatrics University of Minnesota Medical School Minneapolis, Minnesota 55455

Ray C. Anderson, M.D. Department of Pediatrics University of Minnesota Hospitals Minneapolis, Minnesota 55455

Leonard Apt, M.D. Jules Stein Eye Institute UCLA School of Medicine Los Angeles, California 90024
Rene A. Arcilla, M.D. Department of Pediatrics The University of Chicago Wyler Children's Hospital 950 East 59th Street Chicago, Illinois 60637

James B. Arey, M.D.

215 Avon Road

Narberth, Pennsylvania 19072

Peter A. M. Auld, M.D.

525 East 68th Street

Department of Pediatrics

New York, New York 10021

Mary Ellen Avery, M.D.

Montreal Children's Hospital

Montreal 25, Quebec, Canada

Elia M. Ayoub, M.D.

Department of Pediatrics

University of Florida

College of Medicine

Gainesville, Florida 32601

Henry Welles Baird, III, M.D.

2600 N. Lawrence Street

Philadelphia, Pennsylvania 19133

Guilio J. Barbero, M.D.

Hahnemann Medical College \& Hospital 235 N. 15th Street

Philadelphia, Pennsylvania 19102

Frederick W. Barnes, Jr., M.D.

Adams House

12 George Street

Providence, Rhode Island 02906

Lewis A. Barness, M.D.

36th and Spruce Streets

Philadelphia, Pennsylvania 19146

Henry L. Barnett, M.D.

Department of Pediatrics

Albert Einstein College of Medicine

New York, N.Y. 10461

David Baum, M.D.

Department of Pediatrics

Stanford University Medical Center Stanford, California 94305

Marc O. Beem, M.D.

Bobs Roberts Memorial Hospital for Children

920 East 59th Street

Chicago, Illinois 60637
Franklin C. Behrle, M.D. Department of Pediatrics New Jersey College of Medicine Martland Hospital Unit 65 Bergen Street Newark, New Jersey 07107

George Benzing, III, M.D. Division of Cardiology Children's Hospital Elland and Bethesda Avenues Cincinnati, Ohio 45229

William Berenberg, M.D 300 Longwood Avenue Boston, Massachusetts 02115

William H. Bergstrom, M.D. State University of New York Upstate Medical Center 766 Irving Avenue Syracuse, N.Y. 13210

Sumner Berkovich, M.D. 66 Winn Road Cumberland Center, Maine 04021

Jay Bernstein, M.D. William Beaumont Hospital Royal Oak, Michigan 48072

Samuel S. Bernstein, M.D. 1520 W. Seven Mile Detroit, Michigan 48203

Samuel Bessman, M.D. Department of Pharmacology University of Southern California School of Medicine Los Angeles, California 90033

William A. Blanc, M.D. Babies Hospital 3975 Broadway New York, N.Y. 10032

Saul Blatman, M.D. Department of Pediatrics Beth Israel Hospital 10 Nathan D. Perlman Place New York, N.Y. 10003

Russell J. Blattner, M.D. Baylor University Medical College Houston, Texas 77025

Robert M. Blizzard, M.D. Harriet Lane Home Johns Hopkins Hospital Baltimore, Maryland 21205 


\section{SPR Emeritus}

Thomas R. Boggs, M.D.

The Children's Hospital of Philadelphia 1740 Bainbridge Street

Philadelphia, Pennsylvania 19146

Alfred M. Bongiovanni, M.D.

Children's Hospital of Philadelphia

1740 Bainbridge Street

Philadelphia, Pennsylvania 19146

Wayne H. Borges, M.D.

Children's Memorial Hospital

707 West Fullerton Avenue

Chicago, Illinois 60614

James F. Bosma, M.D.

Oral \& Pharyngeal Development Section National Institute of Dental Research National Institutes of Health

Bethesda, Maryland 20014

William L. Bradford, M.D.

Strong Memorial Hospital

260 Crittenden Blvd.

Rochester, N.Y. 14620

Ira K. Brandt, M.D.

Department of Pediatrics

Indiana University School of Medicine

1100 West Michigan Street

Indianapolis, Indiana 46202

Patrick F. Bray, M.D.

Department of Pediatrics

University of Utah College of Medicine

Salt Lake City, Utah 84112

W. Roy Breg, M.D.

Southbury Training School

Southbury, Connecticut 06488

Robert L. Brent, M.D.

Stein Research Center

Jefferson Medical College

920 Chancellor Street

Philadelphia, Pennsylvania 19107

William A. Brodsky, M.D.

220 East 23rd Street

New York, N.Y. 10010

Audrey K. Brown, M.D.

Department of Pediatrics

Medical College of Georgia

Augusta, Georgia 30902

Katherine G. Brownell, M.D.

119 East 78th Street

New York, N.Y. 10021

Hilde Bruch, M.D.

4 East 89th Street

New York, N.Y. 10028
Erika Bruck, M.D.

Children's Hospital

219 Bryant Street

Buffalo, New York 14222

Saul W. Brusilow, M.D.

Harriet Lane Home

Johns Hopkins University

Baltimore, Maryland 21205

Joseph H. Burchenal, M.D.

444 East 68th Street

New York, N.Y. 10021

L. Joseph Butterfield, M.D.

The Children's Hospital

Nineteenth Avenue at Downing

Denver, Colorado 80218

Randolph K. Byers, M.D.

300 Longwood Avenue

Boston, Massachusetts 02115

John P. Caffey, M.D.

Children's Hospital of Pittsburgh

125 DeSoto Street

Pittsburgh, Pennsylvania 15213

Philip L. Calcagno, M.D.

Georgetown University Hospital

3800 Reservoir Drive, N.W.

Washington, D.C. 20007

Alvro M. Camacho, M.D.

Department of Pediatrics

University of Tennessee

James K. Dobbs Research Institute

951 Court Avenue

Memphis, Tennessee 38103

Jose Cara, M.D.

86 East 49th Street

Brooklyn, N.Y. 11203

Benjamin W. Carey, M.D.

142 Second Avenue

Westwood, New Jersey 07675

Merl J. Carson, M.D.

Children's Hospital

Anaheim, California 92705

Robert E. Carter, M.D.

Department of Pediatrics

State University of Iowa

Iowa City, Iowa 52240

Ralph Cash, M.D.

15705 West Ten Mile Road

Southfield, Michigan 48075
Donald E. Cassels, M.D.

Bobs Roberts Memorial Hospital

920 East 59th Street

Chicago, Illinois 60637

Caroline A. Chandler, M.D.

Bittersweet

Wagon Wheel Road

Glen Arm, Maryland 21057

Robert M. Chanock, M.D.

7001 Longwood Drive

Bethesda, Maryland 20014

Charles C. Chapple, M.D.

8517 Indian Hills Drive

Omaha, Nebraska 68114

Barton Childs, M.D.

Johns Hopkins Hospital

Baltimore, Maryland 21205

J. Julian Chisholm, Jr., M.D.

Baltimore City Hospitals

4940 Eastern Avenue

Baltimore, Maryland 21224

Amos U. Christie, M.D.

Vanderbilt University

Nashville, Tennessee 37203

Andrew L. Chute, M.D.

Hospital for Sick Children

555 University Avenue

Toronto 2, Ontario, Canada

George W. Clayton, M.D.

Department of Pediatrics

Baylor University College of Medicine

1200 M.D. Anderson Blvd.

Houston, Texas 77025

William W. Cleveland, M.D.

Department of Pediatrics

University of Miami School of Medicine

1700 N.W. 10th Avenue

Miami, Florida 33136

Stewart H. Clifford, M.D.

221 Longwood Avenue

Boston, Massachusetts 02115

W. A. Cochrane, M.D.

Dean of Medicine

University of Calgary

Calgary, Alberta, Canada

Flossie Cohen, M.D.

Child Research Center of Michigan

3901 Beaubien

Detroit, Michigan 48201 


\section{SPR Emeritus}

Sidney Q. Cohlan, M.D.

566 1st Avenue

New York, N.Y. 10016

Eleanor Colle, M.D.

Montreal Children's Hospital

2300 Tupper Street

Montreal 25, Quebec, Canada

James D. Connor, M.D.

Department of Pediatrics

University of California at San Diego

School of Medicine

La Jolla, California 92037

Charles D. Cook, M.D.

Department of Pediatrics

Yale Medical School

333 Cedar Street

New Haven, Connecticut 06510

Robert E. Cooke, M.D.

Department of Pediatrics

Johns Hopkins Hospital

Baltimore, Maryland 21205

Lewis L. Coriell, M.D.

Institute for Medical Research

Copewod Street

Camden, New Jersey 08103

Marvin Cornblath, M.D.

Department of Pediatrics

University of Maryland

School of Medicine

Baltimore, Maryland 21201

Warren M. Cox, Jr., Ph.D. 9202 Petersburg Road Evansville, Indiana 47711

John M. Craig, M.D. Boston Lying-In Hospital 221 Longwood Avenue Boston, Massachusetts 02115

Robert L. Cranny, M.D. 4307 Governor Drive San Diego, California 92122

John D. Crawford, M.D. Massachusetts General Hospital Boston, Massachusetts 02114

John F. Crigler, Jr., M.D. 300 Longwood Avenue Boston, Massachusetts 02115

Charles S. Culotta, M.D. 291 Whitney Avenue New Haven, Connecticut 06510
Edward C. Curnen, Jr., M.D.

College of Physicians and Surgeons

630 West 168th Street

New York, N.Y. 10032

Charles W. Daeschner, Jr. M.D.

University of Texas Medical Branch

Galveston, Texas 77550

Francis J. Dammann, Jr., M.D.

University of Virginia Medical School

Charlottesville, Virginia 22904

Joseph Dancis, M.D.

New York University School of Medicine 550 First Avenue

New York, N.Y. 10016

Raphael David, M.D.

Department of Pediatrics

New York University College of Medicine

Bellevue Hospital

New York, N.Y. 10016

Murray Davidson, M.D.

The Bronx-Lebanon Hospital Center Grand Concourse and Mt. Eden Parkway Bronx, N. Y. 10457

Richard L. Day, M.D.

Lakeview Terrace

Westbrook, Connecticut 06498

William C. Deamer, M.D.

Department of Pediatrics

University of California Medical Center

San Francisco, California 94122

Robert W. Deisher, M.D.

University of Washington

School of Medicine

Department of Pediatrics

Seattle, Washington 98105

William J. A. DeMaria, M.D.

Duke Hospital

Durham, North Carolina 27706

George R. DeMuth, M.D.

Department of Pediatrics and Communicable Diseases

University of Michigan Medical Center

Ann Arbor, Michigan 48104

Carolyn Denning, M.D.

Babies Hospital

Columbia-Presbyterian Hospital

3975 Broadway

New York, New York 10032
Floyd W. Denny, Jr., M.D.

Department of Pediatrics

University of North Carolina

School of Medicine

Chapel Hill, North Carolina 27514

Murdina M. Desmond, M.D.

Department of Pediatrics

Baylor University College of Medicine

1200 M.D. Anderson Blvd.

Houston, Texas 77025

Louis K. Diamond, M.D.

Children's Hospital

300 Longwood Avenue

Boston, Massachusetts 02115

Angelo M. DiGeorge, M.D.

St. Christopher's Hospital for Children

2600 N. Lawrence Street

Philadelphia, Pennsylvania 19133

Paul A. di Sant'Agnese, M.D.

Chief, Pediatric Metabolism Branch

National Institute of Arthritis and Metabolic Disease

National Institutes of Health

Bethesda, Maryland 20014

Issac Djerassi, M.D.

The Children's Hospital of Philadelphia

1740 Bainbridge Street

Philadelphia, Pennsylvania 19146

Philip R. Dodge, M.D.

Department of Pediatrics

Washington University School of Medicine

St. Louis, Missouri 63110

Alan K. Done, M.D.

Department of Pediatrics

University of Utah Medical Center

Salt Lake City, Utah 84112

George N. Donnell, M.D.

Children's Hospital Society of Los Angeles 4614 Sunset Blvd.

Los Angeles, California 90027

Albert Dorfman, M.D.

Department of Pediatrics

University of Chicago

Chicago, Illinois 60637

Jacques R. Ducharme, M.D.

L'Hôpital Sainte Justine

3175 Ste. Catherine Road

Montrẹal 26, Quebec, Canada

Frederick J. Eagle, M.D.

New York Medical College

106th Street \& 5 th Avenue

New York, N.Y. 10029 


\section{SPR Emeritus}

J. Harry Ebbs, M.D.

49 St. George Street

Toronto 5, Ontario, Canada

Walter R. Eberlein, M.D.

(Last address available)

The Children's Hospital of Philadelphia

1740 Bainbridge Street

Philadelphia, Pennsylvania 19146

Thomas J. Egan, M.D.

Children's Memorial Hospital

2300 Children's Plaza

Chicago, Illinois 60614

Heinz F. Eichenwald, M.D.

Southwestern Medical School

The University of Texas

5323 Harry Hines Blvd.

Dallas, Texas 75235

Donald V. Eitzman, M.D.

Department of Pediatrics

University of Florida Medical School

Gainesville, Florida 32601

Robert S. Ely, M.D.

2000 South 13th East

Salt Lake City, Utah 84104

George C. Emmanouilides, M.D.

Harbor General Hospital

1000 West Carson Street

Torrance, California 90509

Mary Allen Engle, M.D.

New York Hospital

525 E. 68th Street

New York, N.Y. 10021

Marion E. Erlandson, M.D.

Naples Medical Center

831-4th Avenue North

Naples, Florida 33940

James N. Etteldorf, M.D.

University of Tennessee

College of Medicine

Memphis, Tennessee 38103

Harold K. Faber, M.D.

Presbyterian Medical Center

San Francisco, California 94115

Frank Falkner, M.D.

Director, Fels Research Institute for the Study of Human Development

Yellow Springs, Ohio 45387

Sidney Farber, M.D.

Children's Hospital

300 Longwood Avenue

Boston, Massachusetts 02115
Lee E. Farr, M.D.

1550 Oxford Street

Berkeley, California 94709

Gladys J. Fashena, M.D.

University of Texas

Southwestern Medical School

5323 Harry Hines Blvd.

Dallas, Texas 75235

Harry A. Feldman, M.D.

State University of New York Upstate Medical Center

766 Irving Avenue

Syracuse, N.Y. 13210

Francis X. Fellers, M.D.

Metabolic Division

The Children's Hospital

300 Longwood Avenue

Boston, Massachusetts 02115

Angella D. Ferguson, M.D.

3975 Hamlet Place

Chevy Chase, Maryland 20015

Senih Fikrig, M.D.

Department of Pediatrics

Downstate Medical Center

450 Clarkson Avenue

Brooklyn, New York 11203

Lloyd J. Filer, Jr., M.D.

University Hospitals

Department of Pediatrics

University of Iowa

Iowa City, Iowa 52240

Laurence Finberg, M.D.

Montefiore Hospital

210th St. and Barnbridge Avenue

New York, N.Y. 10467

Daniel D. Fleisher, M.D.

Temple University

School of Medicine

Broad and Ontario Streets

Philadelphia, Pennsylvania 19140

Alfred L. Florman, M.D.

School of Medical Sciences

University of the Pacific

Pacific Medical Center

P.O. Box 7999

San Francisco, California 94120

Samuel J. Fomon, M.D.

Department of Pediatrics

University Hospitals

Iowa City, Iowa 52240
Gilbert B. Forbes, M.D.

Department of Pediatrics

University of Rochester

School of Medicine

260 Crittenden Blvd.

Rochester, N.Y. 14620

Richard L. Fowler, M.D.

L.S.U. School of Medicine

1542 Tulane Avenue

New Orleans, Louisiana 70112

Donald Fraser, M.D.

Hospital for Sick Children

555 University Avenue

Toronto, Canada

F. C. Fraser, M.D.

Children's Memorial Hospital

1615 Cedar Avenue

Montreal 25, Quebec, Canada

Donald Fredrickson, M.D.

National Heart Institute

National Institutes of Health

Bethesda, Maryland 20014

Sidney Friedman, M.D. 1740 Bainbridge Street

Philadelphia, Pennsylvania 19146

D. Carleton Gajdusek, M.D.

National Institute of Neurological Diseases \& Blindness

National Institutes of Health

Bethesda, Maryland 20014

James L. Gamble, M.D.

200 Wyndhurst

Baltimore, Maryland 21210

Lytt I. Gardner, M.D.

State University of New York

Upstate Medical Center

Syracuse, N.Y. 13210

Sydney S. Gellis, M.D.

20 Ash Street

Boston, Massachusetts 02111

Leo J. Geppert, M.D.

224 Newbury Terrace

San Antonio, Texas 78209

Park S. Gerald, M.D.

The Children's Hospital

300 Longwood Avenue

Boston, Massachusetts 02115

Horace Gezon, M.D.

Department of Pediatrics

Boston University School of Medicine

818 Harrison Avenue

Boston, Massachusetts 02118 


\section{SPR Emeritus}

Hossein Ghadimi, M.D.

506 6th Street

Brooklyn, N.Y. 11215

Gordon E. Gibbs, M.D.

University of Nebraska

College of Medicine

42nd and Dewey Avenue

Omaha, Nebraska 68105

Lewis Gibson, M.D.

1103 Forest Avenue

Wilmette, Illinois 60091

John H. Githens, M.D.

Department of Pediatrics

University of Colorado Medical Center

4200 East Ninth Avenue

Denver, Colorado 80220

David Gitlin, M.D.

Children's Hospital of Pittsburgh

125 DeSoto Street

Pittsburgh, Pennsylvania 15213

Louis Gluck, M.D.

Department of Pediatrics

University of California, San Diego

School of Medicine

La Jolla, California 92037

Eli Gold, M.D.

Cleveland Metropolitan General Hospital 3395 Scranton Road

Cleveland, Ohio 44109

Richard B. Goldbloom, M.D.

c/o Children's Hospital

Halifax, Nova Scotia

Robert Good, M.D.

Department of Pediatrics

University of Minnesota

Minneapolis, Minnesota 55455

Thomas A. Good, M.D.

Milwaukee Children's Hospital

Department of Pediatrics

$1700 \mathrm{~W}$. Wisconsin Avenue

Milwaukee, Wisconsin 53233

T. Campbell Goodwin

Mary Imogene Bassett Hospital

Cooperstown, New York 13326

Harry H. Gordon, M.D.

Department of Pediatrics

Albert Einstein College of Medicine

Eastchester Road \& Morris Park Avenue New York, N.Y. 10061

Bruce D. Graham, M.D.

The Children's Hospital

Columbus, Ohio 43205
George G. Graham, M.D.

Johns Hopkins University

615 N. Wolfe Street

Baltimore, Maryland 21205

Morris Green, M.D.

1100 W. Michigan Street

Indianapolis, Indiana 46202

William T. Green, M.D.

300 Longwood Avenue

Boston, Massachusetts 02115

Melvin Greer, M.D.

Departments of Medicine and Neurology

J. Hillis Miller Health Center

University of Florida

Gainesville, Florida 32601

Donald Gribetz, M.D.

Department of Pediatrics

Mt. Sinai Hospital

New York, N.Y. 10029

Robert E. Gross, M.D.

300 Longwood Avenue

Boston, Massachusetts 02115

Ruth T. Gross, M.D.

Department of Pediatrics

Mount Zion Hospital

1600 Divisadero Street

San Francisco, California 94115

Samuel Gross, M.D.

Babies and Children's Hospital

2103 Adelbert Road

Cleveland, Ohio 44106

Burton Jay Grossman, M.D.

Department of Pediatrics

University of Chicago School of Medicine

950 East 59th Street

Chicago, Illinois 60637

Moses Grossman, M.D.

Department of Pediatrics

University of California Medical Center

San Francisco, California 94122.

Clifford G. Grulee, Jr., M.D.

College of Medicine

Eden Avenue \& Bethesda

Cincinnati, Ohio 45229

Melvin Grumbach, M.D.

Department of Pediatrics

University of California Medical Center

San Francisco, California 94122
Jerome A. Grunt, M.D.

Department of Pediatrics

University of Missouri in Kansas City

\& Children's Mercy Hospital

24th at Gillham Road

Kansas City, Missouri 64108

Harriet G. Guild, M.D.

Johns Hopkins Hospital

Baltimore, Maryland 21205

Warren G. Guntheroth, M.D.

Department of Pediatrics

University of Washington

Seattle, Washington 98105

Herbert A. Haessler, M.D.

140 Fourth Avenue

Waltham, Massachusetts 02154

Robert J. Haggerty, M.D.

Department of Pediatrics

University of Rochester

School of Medicine

Rochester, N.Y. 14620

Gershon Hait, M.D.

Department of Pediatrics

Albert Einstein College of Medicine

1300 Morris Park Avenue

Bronx, New York 10461

Robert N. Hamburger, M.D.

University of California, San Diego

School of Medicine

La Jolla, California 92037

Bengt L. K. Hamilton, M.D.

110 La Paloma

Santa Fe, New Mexico 87501

Denman Hammond, M.D.

Children's Hospital of Los Angeles

4614 Sunset Blvd.

Los Angeles, California 90027

Janet B. Hardy, M.D.

Box 188

Glenarm, Maryland 21057

Paul H. Hardy, M.D.

Box 98

Glenarm, Maryland 21057

Kendrick Hare, M.D.

University of Alabama

School of Medicine

Birmingham, Alabama 35233

Herbert S. Harned, Jr., M.D.

Department of Pediatrics

University of North Carolina

School of Medicine

Chapel Hill, North Carolina 27514 


\section{SPR Emeritus}

Jerome S. Harris, M.D.

Duke University School of Medicine

Durham, North Carolina 27706

Ruth C. Harris, M.D.

3975 Broadway

New York, N.Y. 10032

\section{T. N. Harris, M.D.}

Children's Hospital of Philadelphia

1740 Bainbridge Street

Philadelphia, Pennsylvania 19146

Harold E. Harrison, M.D.

Baltimore City Hospitals

4940 Eastern Avenue

Baltimore, Maryland 21224

James C. Haworth, M.D.

Children's Hospital

685 Bannatyne Avenue

Winnipeg 3, Manitoba, Canada

Felix P. Heald, M.D.

Department of Pediatrics

University of Maryland Hospital

22 South Greene Street

Baltimore, Maryland 21201

Ernest M. Heimlich, M.D.

(Last address available)

County of Los Angeles

Harbor General Hospital

1000 W. Carson Street

Torrance, California 90509

Douglas C. Heiner, M.D.

McGill University Clinic

Royal Victoria Hospital

687 Pine West

Montreal 2, Canada

Werner Henle, M.D.

Children's Hospital

1740 Bainbridge Street

Philadelphia, Pennsylvania 19146

Albert V. Hennessy, M.D.

2128 Melrose

Ann Arbor, Michigan 48104

Ray Hepner, Jr., M.D.

University Hospital

Baltimore, Maryland 21201

Robert H. High, M.D.

Henry Ford Hospital

2799 W. Grand Avenue

Detroit, Michigan 48202
Donald A. Hillman, M.D.

Department of Endocrinology

Room 1131, Montreal Children's Hospital

2300 Tupper Street

Montreal 25, Quebec, Canada

Horace L. Hodes, M.D.

Mt. Sinai Hospital

11 East 100th Street

New York, N.Y. 10029

Julien I. E. Hoffman, M.D.

Department of Pediatrics

University of California Medical Center

San Francisco, California 94122

Nancy Hinkle Holland, M.D.

Department of Pediatrics

University of Kentucky Medical Center

Lexington, Kentucky 40506

Malcolm A. Holliday, M.D.

Department of Pediatrics

San Francisco General Hospital

1001 Potrero Street

San Francisco, California 94110

L. Emmett Holt, Jr., M.D.

Bellevue Hospital

26th and 1st Avenue

New York, N.Y. 10016

Icie Macy Hoobler, M.D.

502 Burson Place

Ann Arbor, Michigan 48104

Philip J. Howard, M.D.

Henry Ford Hospital

Detroit, Michigan 48202

Doris A. Howell, M.D.

Women's College of Pennsylvania

3300 Henry Avenue

Philadelphia, Pennsylvania 19129

John P. Hubbard, M.D.

3930 Chestnut Street

Philadelphia, Pennsylvania 19104

James Gilliam Hughes, M.D.

Department of Pediatrics

University of Tennessee

Frank T. Tobey Memorial Children's Hospital 860 Madison Avenue

Memphis, Tennessee 38103

Klaus Hummeler, M.D.

Children's Hospital of Philadelphia

1740 Bainbridge Street

Philadelphia, Pennsylvania 19146

Andrew Hunt, M.D.

510 Northlawn

East Lansing, Michigan 48233
Carolyn C. Huntley, M.D.

Wake Forest College

The Bowman Gray School of Medicine

Winston-Salem, North Carolina 27103

George S. Husson, M.D.

State University of New York

Upstate Medical Center

766 Irving Avenue

Syracuse, N.Y. 13210

Theodore H. Ingalls, M.D.

Epidemiology Study Center

113 Lincoln Street

Framingham, Massachusetts 01701

Robert L. Jackson, M.D.

University of Missouri

School of Medicine

Columbia, Missouri 65202

Smilja Jakovcic-Rabinowitz, M.D. Department of Medicine

University of Chicago

950 East 59th Street

Chicago, Illinois 60637

John A. James, M.D.

Rancho Los Amigos Hospital

Room 1, 900 Bldg.

7601 Imperial Highway

Downey, California 90242

L. Stanley James, M.D.

Presbyterian Hospital

622 West 168th St.

New York, N.Y. 10032

Charles A. Janeway, M.D.

Children's Hospital

300 Longwood Avenue

Boston, Massachusetts 02115

Melvin E. Jenkins, M.D.

Department of Pediatrics

University of Nebraska

College of Medicine

Omaha, Nebraska 68105

Lois Johnson, M.D.

4411 Osaga Avenue

Philadelphia, Pennsylvania 19104

Joseph A. Johnston, M.D.

Henry Ford Hospital

Detroit, Michigan 48202

Douglas E. Johnstone, M.D.

1400 Mt. Hope Avenue

Rochester, N.Y. 14620 


\section{SPR Emeritus}

Howard A. Joos, M.D.

Maimonides Hospital

4802 10th Avenue

Brooklyn, N.Y. 11219

Barbera Jones, M.D. Department of Pediatrics University of West Virginia School of Medicine Morgantown, West Virginia 26505

Hugh W. Josephs, M.D. 915 Rolandvue Road Ruxton, Maryland 21204

Benjamin M. Kagan, M.D. 5005 Finley Avenue Los Angeles, California 90027

Eugene Kaplan, M.D. Sinai Hospital Baltimore, Maryland 21215

Samuel Kaplan, M.D. Children's Hospital Elland Avenue \& Bethesda Cincinnati, Ohio 45229

Selna Kaplan, M.D. Department of Pediatrics University of California San Francisco, California 94122

Solomon A. Kaplan, M.D. Department of Pediatrics UCLA Medical Center Los Angeles, California 90024

Samuel Karelitz, M.D. 270-05 76th Avenue New Hyde Park, N.Y. 11040

David T. Karzon, M.D. Department of Pediatrics Vanderbilt University School of Medicine Nashville, Tennessee 37203

Chris P. Katsampes, M.D. Warner-Lambert Research Institute Morris Plains, New Jersey 07950

Michael Katz, M.D.

Columbia University School of Public Health 630 West 168th Street New York, New York 10032

Samuel L. Katz, M.D. Department of Pediatrics Duke University School of Medicine Durham, North Carolina 27706
Robert Kaye, M.D.

1740 Bainbridge Street

Philadelphia, Pennsylvania 19146

John D. Keith, M.D.

Hospital for Sick Children

555 University Avenue

Toronto 2, Ontario, Canada

Vincent C. Kelley, M.D. Department of Pediatrics University of Washington Seattle, Washington 98105

Weston Maynard Kelsey, M.D. Bowman Gray School of Medicine Winston-Salem, North Carolina 27103

C. Henry Kempe, M.D. University of Colorado Medical Center 4200 East Ninth Avenue Denver, Colorado 80220

Charles Kennedy, M.D. Department of Pediatrics Georgetown University School of Medicine 3800 Reservoir Road Washington, D. C. 20007

Gerald A. Kerrigan, M.D. Dean of Medicine Marquette School of Medicine 561 N. 15th Street Milwaukee, Wisconsin 53233

Sidney Kibrick, M.D. Infectious Disease \& Virology Section Massachusetts Memorial Hospital 750 Harrison Avenue

Boston, Massachusetts 02118

Henry N. Kirkman, M.D.

Department of Pediatrics

University of North Carolina

School of Medicine

Chapel Hill, North Carolina 27514

John A. Kirkpatrick, Jr., M.D. St. Christopher's Hospital for Children 2600 N. Lawrence Street Philadelphia, Pennsylvania 19133

Marshall Klaus, M.D. Babies and Children's Hospital 2103 Adelbert Road Cleveland, Ohio 44106

Robert Klein, M.D. Boston City Hospital 818 Harrison Avenue Boston, Massachusetts 02118
Barbara M. Korsch, M.D. Children's Hospital 4614 Sunset Blvd. Los Angeles, California 90027

Avinoam Kowarski, M.D. Department of Pediatrics Johns Hopkins University School of Medicine Baltimore, Maryland 21205

Benjamin Kramer, M.D. 4802 Tenth Avenue Brooklyn, N.Y. 11219

Norman Kretchmer, M.D. Department of Pediatrics Stanford Medical Center 300 Pasteur Drive Palo Alto, California 94304

William Krivit, M.D. Department of Pediatrics University of Minnesota The Medical School Minneapolis, Minnesota 55455

Saul Krugman, M.D. New York University College of Medicine 550 First Avenue New York, N.Y. 10016

M. Eugene Lahey, M.D. Department of Pediatrics University of Utah Medical Center Salt Lake City, Utah 84112

Benjamin H. Landing, M.D. Children's Hospital 4614 Sunset Blvd. Los Angeles, California 90027

Jonathan T. Lanman, M.D. State University of New York 450 Clarkson Avenue Brooklyn, N.Y. 11203

Bernard Laski, M.D. Hospital for Sick Children 555 University Avenue Toronto 2, Ontario, Canada

Robert B. Lawson, M.D. Northwestern University Wieboldt Hall \#119 339 E. Chicago Avenue Chicago, Illinois 60614

Sanford L. Leikin, M.D. Research Foundation

Children's Hospital of the District of Columbia

2125 13th Street N.W. Washington, D.C. 20009 
Miriam Lending, M.D. Department of Pediatrics New York Medical College 1 East 105th Street New York, N.Y. 10029

Martha L. Lepow, M.D. University of Connecticut School of Medicine-McCook Hospital 2 Holcomb Street Hartford, Connecticut 06221

O. Robert Levine, M.D. Department of Pediatrics New Jersey College of Medicine and Dentistry

100 Bergen Street

Newark, New Jersey 07103

John A. Lichty, Jr., M.D. 2544 Bellaire Street Denver, Colorado 80207

Jerome Liebman, M.D. 2224 Elandon Drive Cleveland Heights, Ohio 44106

Jack Light, M.D. 465 N. Roxbury Drive Beverly Hills, California 90210

Neil N. Litman, M.D. Children's Medical Group 5830 Overhill Drive Los Angeles, California 90043

John W. Littlefield, M.D. Massachusetts General Hospital Boston, Massachusetts 02114

Chien Liu, M.D.

University of Kansas Medical Center Kansas City, Kansas 66103

Samuel Livingston, M.D. 1039 St. Paul Street Baltimore, Maryland 21202

Charles C. Lobeck, M.D. University Hospitals Madison, Wisconsin 53706

Andrew Lorincz, M.D. Director, Center for Development \& Learning Disorders

University of Alabama in Birmingham Birmingham, Alabama 35233

Charles U. Lowe, M.D. Bldg. 31 NICHD National Institutes of Health Bethesda, Maryland 20014
Lula O. Lubchenco, M.D.

716 Monaco Parkway

Denver, Colorado 80220

Jerold F. Lucey, M.D.

DeGoesbriand Hospital

University of Vermont

College of Medicine

Burlington, Vermont 05410

A. Leonard Luhby, M.D. Department of Pediatrics New York Medical College 1249 Fif th Avenue New York, N.Y. 10029

Paul R. Lurie, M.D. Division of Cardiology Children's Hospital of Los Angeles 4614 Sunset Blvd. Los Angeles, California 90027

Joshua Lynfield, M.D. N.Y.U. Medical Center 566 First Avenue New York, N.Y. 10016

Robert A. Lyon, M.D. Children's Hospital Elland Avenue \& Bethesda Cincinnati, Ohio 45229

Loren G. MacKinney, M.D. Medical Director East Los Angeles Child and Youth Clinic 929 North Bonnie Beach Place Los Angeles, California 90063

Bruce Mackler, M.D. University of Washington School of Medicine Seattle, Washington 98105

Marion Maresh, M.D. Child Research Council 4200 East Ninth Avenue Denver, Colorado 80220

John W. Maroney, M.D. 1207 Delaware Avenue Wilmington, Delaware 19806

LeRoy W. Matthews, M.D. University Hospitals of Cleveland 2065 Adelbert Road Cleveland, Ohio 44106

Alvin M. Mauer, M.D. Children's Hospital Research Foundation Elland and Bethesda Avenues Cincinnati, Ohio 45229
Charles D. May, M.D. Department of Pediatrics Bellevue Hospital New York, N.Y. 10016

A. James McAdams, M.D. Department of Pathology Children's Hospital Elland \& Bethesda Avenues Cincinnati, Ohio 45229

Robert McAllister, M.D. Division of Virology Children's Hospital P.O. Box 54700, Terminal Annex Los Angeles, California 90054

Angus M. McBryde, M.D. Duke Hospital Durham, North Carolina 27706

Ernest E. McCoy, M.D. Department of Pediatrics University of Alberta Edmonton, Alberta, Canada

John F. McCreary, M.D. Faculty of Medicine University of British Columbia Vancouver 8, B.C., Canada

Wallace W. McCrory, M.D. Department of Pediatrics The New York Hospital Cornell Medical Center 525 East 68th Street New York, N.Y. 10021

Donovan J. McCune, M.D. The Permanente Hospital 2600 Alameda Street Vallejo, California 94590

Arthur E. McElfresh, M.D.

Cardinal Glennon Memorial Hospital for Children

1465 S. Grand Blvd.

St. Louis, Missouri 63104

Aims C. McGuinness, M.D. 721 Prospect Avenue Princeton, New Jersey 08540

Rustin McIntosh, M.D. Tyringham, Massachusetts 01264

Robert J. McKay, Jr., M.D. University of Vermont College of Medicine Burlington, Vermont 05410

Charles F. McKhann, M.D. 485 Park Avenue New York, N.Y. 10022 


\section{SPR Emeritus}

Donald M. McLean, M.D. Department of Medical Microbiology The University of British Columbia Vancouver 8, B.C., Canada

Campbell B. McMillan, M.D. Department of Pediatrics University of North Carolina School of Medicine Chapel Hill, North Carolina 27514

Gilbert W. Mellin, M.D. College of Physicians \& Surgeons Columbia University 630 West 168th Street New York, N.Y. 10032

Robert B. Mellins, M.D. 3975 Broadway New York, New York, 10032

Jack Metcoff, M.D.

Department of Pediatrics University of Oklahoma School of Medicine Oklahoma City, Oklahoma 73104

Richard H. Michaels, M.D. Children's Hospital of Pittsburgh 125 DeSoto Street Pittsburgh, Pennsylvania 15213

Claude J. Migeon, M.D. Department of Pediatrics Johns Hopkins Hospital Baltimore, Maryland 21205

C. Arden Miller, M.D. University of North Carolina South Building Chapel Hill, North Carolina 27514

\section{Gerald Miller, M.D.}

Strong Memorial Hospital

Rochester, N.Y. 14620

Herbert C. Miller, M.D. University of Kansas Medical Center Rainbow Boulevard at 39th Street Kansas City, Kansas 66103

Robert A. Miller, M.D.

Department of Pediatrics Illinois College of Medicine 840 South Wood St.

Chicago, Illinois 60612

Robert W. Miller, M.D. National Cancer Institute National Institutes of Health Bethesda, Maryland 20014
J. Gordon Millichap, M.D. Children's Memorial Hospital 707 Fullerton Avenue Chicago, Illinois 60610

Bernard L. Mirkin, M.D. Clinical Pharmacology Section Departments of Pediatrics and Pharmacology

University of Minnesota College of Medicine Minneapolis, Minnesota 55455

Beverly Morgan, M.D. Department of Pediatrics University of Washington School of Medicine Seattle, Washington 98105

Edward A. Mortimer, Jr., M.D. Department of Pediatrics The University of New Mexico Albuquerque, New Mexico 87106

H. David Mosier, M.D. Department of Pediatrics University of California, Irvine College of Medicine Irvine, California 92664

M. Lois Murphy, M.D. Sloan Kettering Institute for Cancer Research 410 East 68th Street New York, N.Y. 10021

Alexander Nadas, M.D. 300 Longwood Avenue Boston, Massachusetts 02115

Victor A. Najjar, M.D. Division of Protein Chemistry Tufts University School of Medicine 136 Harrison Avenue Boston, Massachusetts 02111

Catherine A. Neill, M.D. Harriet Lane Home Cardiac Clinic Johns Hopkins Hospital Baltimore, Maryland 21205

Thomas L. Nelson, M.D. Department of Pediatrics Universities of California, Irvine College of Medicine Irvine, California 92664

Waldo E. Nelson, M.D. 615 Moreno Road Narberth, Pennsylvania 19072
Rosa Lee Nemir, M.D.

N.Y. University School of Medicine

550 First Avenue

New York, N.Y. 10016

Erwin Neter, M.D.

Children's Hospital

Buffalo, N.Y. 14222

Edward B.D. Neuhauser, M.D. Children's Hospital 300 Longwood Avenue Boston, Massachusetts 02115

W.A. Newton, Jr., M.D. The Children's Hospital 17th Street at Livingston Park Columbus, Ohio 43205

Harold M. Nitowsky, M.D. Department of Pediatrics Albert Einstein College of Medicine Eastchester Road \& Morris Park Avenue Bronx, N.Y. 10461

William L. Nyhan, M.D. Department of Pediatrics University of California, San Diego La Jolla, California 92037

Donough O'Brien, M.D. University of Colorado Medical Center 4200 East Ninth Avenue Denver, Colorado 80220

William Obrinsky, M.D. Division of Pediatrics Montefiore Hospital 210th Street \& Bainbridge New York, N.Y. 10467

Gerard B. Odell, M.D. School of Medicine Johns Hopkins University Baltimore, Maryland 21205

Thomas K. Oliver, Jr., M.D. The Children's Hospital 125 DeSoto Street Pittsburgh, Pennsylvania 15213

William J. Oliver, M.D.

Department of Pediatrics and Communicable Diseases University of Michigan Medical Center Ann Arbor, Michigan 48104

Nelson K. Ordway, M.D. Department of Pediatrics Children's Memorial Hospital University of Oklahoma Medical Center 800 N.E. 13th Street Oklahoma City, Oklahoma 73104 


\section{SPR Emeritus}

John J. Osborn, M.D.

Pacific Medical Center

Clay \& Webster Streets

San Francisco, California 94115

Arthur H. Parmelee, M.D.

Department of Pediatrics

UCLA Medical Center

Los Angeles, California 90024

Robert H. Parrott, M.D.

Children's Hospital

2125 13th Street N.W.

Washington, D.C. 20009

Paul R. Patterson, M.D.

Department of Pediatrics

Albany Medical College

Albany, N.Y. 12208

Milton Holliday Paul, M.D.

Children's Memorial Hospital

707 Fullerton Avenue

Chicago, Illinois 60614

Elsa P. Paulsen, M.D.

Department of Pediatrics

Albert Einstein College of Medicine

New York, N.Y. 10461

John Cyril Peterson, M.D.

Milwaukee Children's Hospital

721 N. 17th Street

Milwaukee, Wisconsin 53233

Donald E. Pickering, M.D.

Pediatric Medicine \& Endocrinology

275 Hill Street-Suite 21

Reno, Nevada 89503

Carolyn F. Piel, M.D.

Department of Pediatrics

University of California Medical School

San Francisco Medical Center

San Francisco, California 94122

Joseph B. Pincus, M.D.

881 Washington Avenue

Brooklyn, N.Y. 11225

Donald Pinkel, M.D.

Department of Pediatrics

University of Tennessee

St. Jude's Hospital for Children

332 N. Lauderdale Avenue

Memphis, Tennessee 38103

George Polgar, M.D.

Department of Physiology

The Graduate School of Medicine

University of Pennsylvania

Philadelphia, Pennsylvania 19104
F. Stanley Porter, M.D.

Department of Pediatrics

Duke University Medical Center

Box 2916

Durham, North Carolina 27706

Edith L. Potter, M.D.

Rt. 3, Box 658

Fort Myers, Florida 33901

Edward L. Pratt, M.D.

Children's Hospital Research Foundation

Elland Avenue \& Bethesda

Cincinnati, Ohio 45229

Dane G. Prugh, M.D.

University of Rochester

School of Medicine

Rochester, N.Y. 14620

Charles V. Pryles, M.D.

Jewish Hospital of Brooklyn

555 Prospect Place

Brooklyn, N.Y. 11238

Hope H. Punnett, Ph.D.

St. Christopher's Hospital for Children 2600 N. Lawrence Street

Philadelphia, Pennsylvania 19133

Paul G. Quie, M.D.

Department of Pediatrics

University of Minnesota Medical School

Minneapolis, Minnesota 55455

James J. Quilligan, Jr., M.D.

Director, LLU Virus Lab.

Loma Linda Medical Center

Loma Linda, California 92354

Edward F. Rabe, M.D.

123 Garden Street

Needham, Massachusetts 02192

William J. Rashkind, M.D.

Children's Hospital

1740 Bainbridge Street

Philadelphia, Pennsylvania 19146

Charles H. Read, M.D.

University Hospital

State University of Iowa

Iowa City, Iowa 52240

Gertrude C. Reyersbach, M.D.

330 Dartmouth Street

Boston, Massachusetts 02116

Julius B. Richmond, M.D.

Department of Psychiatry

Children's Hospital

Boston, Massachusetts 02115
Conrad M. Riley, M.D.

2800 East Cedar Street

Denver, Colorado 80209

Harris D. Riley, Jr., M.D.

Children's Memorial Hospital

University of Oklahoma

School of Medicine

Oklahoma City, Oklahoma 73104

Frederick C. Robbins, M.D.

Case Western Reserve University

School of Medicine

2109 Adelbert Road

Cleveland, Ohio 44106

Margaret G. Robinson, M.D.

Department of Pediatrics

State University of New York

Downstate Medical Center

450 Clarkson Avenue

Brooklyn, New York 11203

Robert C. Rosan, M.D.

Department of Pediatrics

Cardinal Glennon Memorial Hospital

1465 South Grand Boulevard

St. Louis, Missouri 63104

Ira M. Rosenthal, M.D.

Department of Pediatrics

University of Illinois

College of Medicine

840 South Wood Street

Chicago, Illinois 60612

S. Graham Ross, M.D.

65 Rosemont Avenue

Montreal 6, Canada

Richard D. Rowe, M.D.

Cardiac Clinic

Children's Medical \& Surgical Center

Johns Hopkins Hospital

Baltimore, Maryland 21205

Mitchell I. Rubin, M.D.

Children's Hospital

219 Bryant Street

Buffalo, N.Y. 14222

Abraham M. Rudolph, M.D.

University of California

San Francisco Medical Center

San Francisco, California 94122

Julius Rutsky, M.D.

Director of Clinical Laboratories

William Beaumont Hospital

3601 West 13 Mile Road

Royal Oak, Michigan 48027 


\section{SPR Emeritus}

Albert B. Sabin, M.D.

2801 New Mexico Avenue, N.W.

Washington, D.C. 20007

Andrew Sass-Kortsak, M.D.

Hospital for Sick Children

555 University Avenue

Toronto, Ontario, Canada

Irwin A. Schafer, M.D.

Case Western Reserve University

Cleveland Metropolitan General

Hospital

3395 Scranton Road

Cleveland, Ohio 44109

Henry W. Scherp, M.D.

National Institute of Dental Research

Bethesda, Maryland 20014

Robert J. Schlegel, M.D.

Department of Pediatrics

Charles R. Drew Postgraduate Medical School

Los Angeles, California 90059

William M. Schmidt, M.D.

Harvard School of Public Health

55 Shattuck Street

Boston, Massachusetts 02115

Edgar J. Schoen, M.D.

Kaiser Foundation Hospital

280 West McArthur Blvd.

Oakland, California 94611

William K. Schubert, M.D.

Children's Hospital Research Foundation

Elland Avenue \& Bethesda

Cincinnati, Ohio 45229

Irving Schulman, M.D.

Department of Pediatrics

Stanford University School of Medicine

Stanford, California 94305

Herbert C. Schwartz, M.D.

Department of Pediatrics

Stanford Medical Center

Stanford, California 94305

Robert Schwartz, M.D.

Department of Pediatrics

Cleveland Metropolitan General Hospital

3395 Scranton Road

Cleveland, Ohio 44109

Roland B. Scott, M.D.

Howard University Medical School

Washington, D.C. 20001

T.F. McNair Scott, M.D.

1740 Bainbridge Street

Philadelphia, Pennsylvania 19146
Stanton Segal, M.D.

Children's Hospital of Philadelphia

1740 Bainbridge Street

Philadelphia, Pennsylvania 19146

Sydney Segal, M.D.

Department of Pediatrics

University of British Columbia

Vancouver, B.C., Canada

William E. Segar, M.D.

Department of Pediatrics

University of Wisconsin Medical Center

1300 University Avenue

Madison, Wisconsin 53706

Milton J.E. Senn, M.D.

333 Cedar Street

New Haven, Connecticut 06510

Nasrollah T. Shahidi, M.D.

Department of Pediatrics

University of Wisconsin

Madison, Wisconsin 53706

Kenneth N.F. Shaw, M.D.

Children's Hospital

4614 Sunset Blvd.

Los Angeles, California 90027

Thomas H. Shepard, M.D.

Department of Pediatrics

University of Washington

School of Medicine

Seattle, Washington 98105

Henry R. Shinefield, M.D.

The Permanente Medical Group

2200 O'Farrell Street

San Francisco, California 94115

Harry Shwachman, M.D.

300 Longwood Avenue

Boston, Massachusetts 02115

Maarten S. Sibinga, M.D.

St. Christopher's Hospital for Children

2600 North Lawrence Street

Philadelphia, Pennsylvania 19133

James B. Sidbury, Jr., M.D.

Department of Pediatrics

Duke University Medical Center

Durham, North Carolina 27706

M. Michael Sigel, Ph.D.

Variety Children's Research Foundation P.O. Box 7278

Miami, Florida 33155

Henry K. Silver, M.D.

University of Colorado Medical Center

4200 East Ninth Avenue

Denver, Colorado 80220
Frederic N. Silverman, M.D.

Children's Hospital

Cincinnati, Ohio 45229

William A. Silverman, M.D.

90 LaCuesta Drive

Greenbrae, California 94904

L. Nelles Silverthorne, M.D.

170 St. George Street

Toronto 5, Ontario, Canada

Norman J. Sissman, M.D.

Hospital for Joint Diseases

1919 Madison Avenue

New York, N.Y. 10035

Thomas R.C. Sisson, M.D.

Department of Pediatrics

Temple University School of Medicine

Broad and Ontario Streets

Philadelphia, Pennsylvania 19140

Robert J. Slater, M.D.

President

Association for the Aid of Crippled

Children

345 East 46th Street

New York, N.Y. 10017

Clement A. Smith, M.D.

300 Longwood Avenue

Boston, Massachusetts 02115

David W. Smith, M.D.

University of Washington

Medical School

Seattle, Washington 98105

Fred G. Smith, Jr., M.D.

Department of Pediatrics

UCLA School of Medicine

Los Angeles, California 90024

George F. Smith, M.D.

341 Kent Road

Riverside, Illinois 60546

J. Darrel Smith, M.D.

Children's Memorial Hospital

University of Oklahoma Medical Center 800 N.E. 13th Street

Oklahoma City, Oklahoma 73104

Margaret H. D. Smith, M.D.

Department of Pediatrics

Tulane University School of Medicine

1430 Tulane Avenue

New Orleans, Louisiana 70112 


\section{SPR Emeritus}

Nathan J. Smith, M.D.

King County Hospital

University of Washington

Department of Pediatrics

Seattle, Washington 98105

Elizabeth M. Smithwick, M.D.

State University of New York

Downstate Medical Center

450 Clarkson Avenue

Brooklyn, New York 11203

Charles E. Snelling, M.D.

I.O.D.E. Children's Centre

New York General Hospital

4001 Leslie Street

Willowdale, Ontario, Canada

Selma E. Snyderman, M.D.

Department of Pediatrics

New York University College of Medicine

550 First Avenue

New York, N.Y. 10016

Edna H. Sobel, M.D.

Albert Einstein College of Medicine

New York, N.Y. 10461

Juan F. Sotos, M.D.

Children's Hospital

Columbus, Ohio 43205

Madison S. Spach, M.D.

Department of Pediatrics

Duke University Medical Center

Durham, North Carolina 27706

Samuel Spector, M.D.

Wyler Children's Hospital

950 E. 59th Street

Chicago, Illinois 60637

Adrian Spitzer, M.D.

Department of Pediatrics

Albert Einstein College of Medicine

1410 Pelham Parkway South

Bronx, New York 10461

Katherine Sprunt, M.D.

Babies Hospital

Columbia-Presbyterian Medical Center

New York, N.Y. 10032

Mildred Stahlman, M.D.

Vanderbilt Hospital

Nashville, Tennessee 37203

Uwe Stave, M.D.

Fells Research Institute

Yellow Springs, Ohio 45387
Alex J. Steigman, M.D.

Department of Pediatrics

Mount Sinai School of Medicine

5 th Avenue at 100th Street

New York, N.Y. 10029

Robert S. Stempfel, Jr., M.D.

Department of Pediatrics

University of California, Davis

Davis, California 95616

Stuart Shelton Stevenson, M.D.

St. Luke's Hospital

113th Street \& Amsterdam Avenue

New York, N.Y. 10025

Gunnar B. Stickler, M.D.

Mayo Clinic

Rochester, Minnesota 55901

Albert V. Stoesser, M.D.

P.O. Box 534

Carmel, California 93921

Daniel Stowens, M.D.

Fountain Street

Clinton, N.Y. 13323

Herbert Strauss, M.D.

Department of Pediatrics

Albany Medical College

New Scotland Avenue

Albany, N.Y. 12208

Cyril S. Stulberg, M.D.

The Child Research Center

Children's Hospital of Michigan

3901 Beaubien Blvd.

Detroit, Michigan 48201

Phillip Sturgeon, M.D.

210 Ocean Avenue, Apt. 406B

Santa Monica, California 90402

James M. Sutherland, M.D.

Children's Hospital Research Foundation

Elland Avenue \& Bethesda

Cincinnati, Ohio 45229

William W. Swanson, M.D.

2376 East 71 st Street

Chicago, Illinois 60649

Michael J. Sweeney, M.D.

Department of Pediatrics

University of Texas Medical School

at San Antonio

7703 Floyd Curl Drive

San Antonio, Texas 78229
Avron Y. Sweet, M.D.

Department of Pediatrics

Cleveland Metropolitan General Hospital

3395 Scranton Road

Cleveland, Ohio 44109

Paul R. Swyer, M.D.

The Hospital for Sick Children

555 University Avenue

Toronto 2, Ontario, Canada

Nathan B. Talbot, M.D.

Massachusetts General Hospital

Fruit Street

Boston, Massachusetts 02114

Norman S. Talner, M.D.

Department of Pediatrics

Yale University School of Medicine

333 Cedar Street

New Haven, Connecticut 06510

Helen B. Taussig, M.D.

Johns Hopkins Hospital

Baltimore, Maryland 21205

Harvey Grant Taylor, M.D.

University of Texas

M.D. Anderson Hospital

Houston, Texas 77025

Paul M. Taylor, M.D.

Elizabeth Steel Magee Hospital

Forbes and Halket Streets

Pittsburgh, Pennsylvania 15213

Louis Thomas, M.D.

New York University

College of Medicine

477 First Avenue

New York, N.Y. 10016

William H. Tooley, M.D.

Department of Pediatrics

University of California

School of Medicine

University of California, San Francisco

San Francisco, California 94122

Phillip L. Townes, M.D.

Departments of Anatomy and Pediatrics

University of Rochester School of Medicine

Rochester, N.Y. 14620

Robert A. Ulstrom, M.D.

Department of Pediatrics

University of Minnesota

Minneapolis, Minnesota 55455

Carlos Vallbona, M.D.

Institute for Rehabilitation and Research

Houston, Texas 


\section{SPR Emeritus}

Lodwyck H. S. Van Mierop, M.D. Department of Pediatrics University of Florida School of Medicine Gainesville, Florida 32601

Judson J. Van Wyk, M.D. University of North Carolina School of Medicine Chapel Hill, North Carolina 27514

Victor C. Vaughan, M.D. St. Christopher's Hospital 2600 N. Lawrence Philadelphia, Pennsylvania 19133

Robert L. Vernier, M.D. Department of Pediatrics The Medical School University of Minnesota Minneapolis, Minnesota 55455

Peter Vlad, M.D. Buffalo Children's Hospital 219 Bryant Street Buffalo, N.Y. 14222

Mary L. Voorhess, M.D. State University of New York Upstate Medical Center Syracuse, N.Y. 13210

Bernard Wagner, M.D. College of Physicians and Surgeons Columbia University 99 Fort Washington Avenue New York, New York 10032

Dwain N. Walcher, M.D. Dean's Office College of Human Development Penn State University University Park, Pennsylvania 16802

Lewis W. Wannamaker, M.D. University of Minnesota Minneapolis, Minnesota 55455

Robert Ward, M.D. Children's Hospital 4614 Sunset Blvd. Los Angeles, California 90027

Josef Warkany, M.D. 3535 Biddle Street Cincinnati, Ohio 45220

Warren J. Warwick, M.D. Department of Pediatrics University of Minnesota Minneapolis, Minnesota 55455

Alfred H. Washburn, M.D. 2257 Ash Street Denver, Colorado 80217
Ralph J. Wedgwood, M.D. University of Washington School of Medicine Seattle, Washington 98105

A. Ashley Weech, M.D. Children's Hospital Research Foundation Elland \& Bethesda Avenues Cincinnati, Ohio 45229

Myron E. Wegman, M.D.

Dean, School of Public Health

University of Michigan

Ann Arbor, Michigan 48104

Paul F. Wehrle, M.D.

Communicable Disease Division

Los Angeles County General Hospital 1200 North State Street

Los Angeles, California 90033

William Weidman, M.D.

Mayo Clinic

Rochester, Minnesota 55902

William B. Weil, Jr., M.D.

Department of Human Development

Michigan State University

308 Olin Health Center

East Lansing, Michigan 48823

Thomas H. Weller, M.D.

Harvard School of Public Health 25 Shattuck Street

Boston, Massachusetts 02115

Herbert Allan Wenner, M.D.

9711 Johnson Drive

Merriam, Kansas

Clark D. West, M.D.

Children's Hospital Research Foundation

Elland Avenue \& Bethesda

Cincinnati, Ohio 45229

Norman C. Wetzel, M.D. 2358 Ardleigh Drive Cleveland Heights, Ohio 44118

Charles A. Weymuller, M.D. 1021 Adams Street S.E. Albuquerque, New Mexico 87108

Warren E. Wheeler, M.D. University of Kentucky School of Medicine Lexington, Kentucky 40506

JoAnne Whitaker, M.D. Education Project/AMA APO San.Francisco, Calif. 96243

Charles F. Whitten, M.D. 5224 St. Antoine Street Detroit, Michigan 48202
Theodore S. Wilder, M.D.

Linden Lane

Sherborn, Massachusetts 01770

James L. Wilson, M.D.

University Hospital

Ann Arbor, Michigan 48104

James R. Wilson, M.D.

State Home and Training School

Grand Junction, Colorado 81501

John F. Wilson, M.D.

Pathologist and Director of Laboratories Primary Children's Hospital Salt Lake City, Utah 84103

William R. Wilson, M.D. 255 Bradley Street New Haven, Connecticut

Robert W. Winters, M.D. Babies Hospital Columbia-Presbyterian Medical Center 622 W. 168th Street New York, N.Y. 10032

James A. Wolff, M.D. Babies Hospital Broadway \& 167th Street New York, N.Y. 10032

Irving J. Wolman, M.D. The Children's Hospital 1740 Bainbridge Street Philadelphia, Pennsylvania 19146

Harrison F. Wood, M.D. Department of Pediatrics Yale University School of Medicine 333 Cedar Street New Haven, Connecticut 06510

Calvin W. Woodruff, M.D. Department of Pediatrics University of Missouri Colǘmbia, Missouri 65202

Paul V. Wooley, Jr., M.D. Children's Hospital of Michigan 5224 St. Antoine Street Detroit, Michigan 48202

Howard G. Worthen, M.D. The University of Texas Southwestern Medical School 5323 Harry Hines Blvd. Dallas, Texas 75235

F. Howell Wright, M.D. 920 East 59th Street Chicago, Illinois 60637

Sumner J. Yaffe, M.D. State University of New York at Buffalo 219 Bryant Street Buffalo, N.Y. 14222 
William C. Yakovac, M.D.

331 Pine Street

Philadelphia, Pennsylvania 19106

Herman Yannet, M.D.

Southbury Training School

Southbury, Connecticut 06488

Francisco Beas, M.D.

Laboratorio de Investigaciones

Escuela de Medicina/Univ de Chile

Casilla 5370

Santiago, Chile

Dr. Moises Behar

Instituto de Nutricion de Centro

America Y Panama, Apartado Postal

1188 Guatemala City

Central America

Cesar Chavarria Bonequi, M.D.

Hospital Infantil de Mexico

Mexico City 7, D.F.

Mexico

Donald B. Cheek, M.D.

Director of Research

Royal Children's Hospital

Melbourne, Victoria 3052

Australia
Martha Yow, M.D.

Baylor University College of Medicine

1200 Moursund Avenue

Houston, Texas 77025

William Zinkham, M.D.

Department of Pediatrics

\section{Society For Pediatric Research MEMBERSHIP LIST 1973-1974 \\ Foreign}

Dr. Joaquin M. Cravioto

Department of Nutrition II

Hospital Infantil de Mexico

Dr. Marques \#162

Mexico 7, D.F.

Pierre E. Ferrier, M.D.

Professor of Pediatrics

University of Geneva

Geneva, Switzerland

Robert Fowler, Jr., M.D.

Royal Children's Hospital

Melbourne N3, Australia

Silvestre Frenk, M.D.

Hospital de Pediatria

Centro Medica Nacional

Mexico 7, D.F.

Gustavo Gordillo, M.D.

Hospital Infantil de Mexico

Dpto. de Nefrologia

Calle Dr. Marquez 162

Mexico 7, D.F.
The Johns Hopkins Hospital

Baltimore, Maryland 21205

Wolf W. Zuelzer, M.D.

Children's Hospital of Michigan

3901 Beaubien Boulevard

Detroit, Michigan 48201

George M. Mảxwell, M.D.

Children's Hospital

Adelaide, Australia

Fernando Monckeberg, M.D.

Casilla 5091

Santiago, Chile

Samuel Rapoport, M.D.

Niederschonhausen

45 Kuckhoffstrasse

Berlin, Germany

H.K.A. Visser, M.D.

Department of Pediatrics

Sophia Children's Hospital

Gordelweg 160

Rotterdam-4, The Netherlands

Colin H.M. Walker, M.D.

Department of Child Health

11 Dudhope Terrace

Dundee, Scotland 